Reprod. Nutr. Dévelop., 1988, 28 (4 A), 857-887

\title{
Growth hormones. 1. Polymorphism. (Minireview)
}

\author{
J. CHARRIER, J. MARTAL
}

Station de Physiologie Animale, I.N.R.A.

E.N.S.A., Place Viala, 34060 Montpellier Cedex, France. Unité Endocrinologie de l'Embryon

I.N.R.A., 78350 Jouy-en-Josas.

Summary. Pituitary growth hormone $(\mathrm{GH})$ is not a single molecular species, but a whole set of similar molecules, the individual specific characteristics of which constitute the polymorphism of this hormone. The present paper deals mainly with various forms of human $\mathrm{GH}$, called "variants », and touches on this polymorphism in other species as well.

The $22 \mathrm{~K}$ variant ( $\mathrm{MW}=22,000$ daltons) is the predominant form of $\mathrm{GH}$ to which all other variants are compared as to chemical structure and biological effect. These variants are classified into two large groups : 1) mass variants, the molecular weight of which is modified in comparison with that of $22 \mathrm{~K}$; these can be subdivided into aggregated and non-aggregated forms, and 2) charge variants with modified electrophoretic mobility. Outside this classification are entities which are not yet well known; these include bioinactive $\mathrm{GH}$, correctly detected by RIA but deprived of biological activity or, on the contrary, strongly bioactive $\mathrm{GH}$ lacking immunoreactivity and consequently difficult to study. Another outsider is the SV-hGH-2 variant encoded from a gene different from the $\mathrm{hGH}-\mathrm{N}$ gene normally coding for the other variants. In this case, the product could be considered a true isohormone of $22 \mathrm{~K}$ and no longer a variant. The pituitary expression of this gene has never been evidenced to date, but according to recent data, it could be expressed at the placental level and be implicated in human placental growth hormone $(\mathrm{hPGH})$ synthesis. hPGH is a newly-found $\mathrm{GH}$ in pregnant women which takes over pituitary $\mathrm{GH}$ from the 25th week onwards.

After the $\mathrm{GH}$ molecules are released by the pituitary in the blood stream, they are partially taken up and carried by binding proteins. The physiological role of this phenomenon could be the setting up of a $\mathrm{GH}$ reservoir and a $\mathrm{GH}$ sparing process since the metabolic clearance rate of the complex $\mathrm{GH}$-binding protein is slower than that of free $\mathrm{GH}$, thus increasing the biological half-life of the hormone.

\section{Introduction.}

Growth hormones $(\mathrm{GH})$ represent a fascinating example of molecular evolution. With prolactins and placental lactogens (PL) also called chorionic somatomammotropins (CS) they are considered to belong to the same hormone super-family because in many species, and especially in humans, they share a number of biological, immunological and structural characteristics (Wallis, 1978 ; Nicoll, 1982). The members of this family are derived from a common ancestral gene that diverged about 400 million years ago into the $\mathrm{GH}$ and the prolactin 
branches (Miller and Eberhardt, 1983). However, human prolactin is thought to derive from a divergence of $\mathrm{GH}$ genes about 20 million years ago, while rat and ruminant prolactins would come from genes of the "prolactin" branch (Miller and Eberhardt, 1983). Placental lactogen hormones probably appeared about 75 million years ago (Martal, 1980) from a duplication of the growth hormone cistron. Though most of the members of this hormone family have specific biological properties, some of them such as hGH (Li, 1972), ovine PL (Martal and Djiane, 1975, 1977; Martal, 1978), bovine PL (Murthy et al., 1982) or primate PL (Josimovitch and Mac Laren, 1962 ; Friesen, 1965; Kaplan and Grumbach, 1965; Florini et al., 1966; Shome and Friesen, 1971) display dual effects characteristic of both lactogenic and somatotropic hormones. The genes of several members of this family have been characterized. They consist of five exons of nearly constant length for the same type of hormones, prolactin genes being much larger (10 to $12 \mathrm{~Kb}$ ) than $\mathrm{GH}$ genes $(2 \mathrm{~Kb}$ ) because of larger introns (Miller and Eberhardt, 1983). In 1976 Sussman et al. showed that hGH biosynthesis was processed by a postribosomal proteolytic modification of a larger molecule, a pre-hGH. In 1980 Goodman et al. identified two different genes ruling hGH synthesis : one denominated hGH-N ( $\mathrm{N}=$ «normal $)$ and accountable for the synthesis of the "basic » 22,000-dalton molecule $(22 \mathrm{~K}$, see fig. 1a), the other called hGH-V (V = « variant $)$ and giving rise to several amino acid changes and deletions inside the molecule.

Primate $\mathrm{GH}$ is the only animal $\mathrm{GH}$ efficient in humans. However, the memory of its common ancestral origin with the $\mathrm{GH}$ of other species is found both in the high percentage of identical primary structures (table 1) and in the fact that certain fragments of non-human $\mathrm{GH}$ exert a more or less pronounced biological effect in humans (Liberti and Miller, 1978; Maciag et al., 1980; Hubbard and Liberti, 1980). According to Kawauchi and Yasuda (1987), GHs elicit four highly conserved domains through phylogenetic evolution; these are aminoacid align-

TABLE 1

Identity between the primary aligned structures of different hormones (from Martal, 1980).

\begin{tabular}{|c|c|c|c|c|c|c|c|c|}
\hline \multicolumn{9}{|c|}{ Number of identical aminoacids } \\
\hline & hCS & $\mathrm{hGH}$ & $\mathrm{oGH}$ & $\mathrm{bGH}$ & $\mathrm{eGH}$ & hPRL & OPRL & pPRL \\
\hline $\mathrm{hCS}$ & & 162 & 112 & 114 & 115 & 48 & 55 & 52 \\
\hline hGH & $85 \%$ & & 122 & 124 & 122 & 51 & 56 & 42 \\
\hline oGH & $59 \%$ & $74 \%$ & & 189 & 173 & 49 & 52 & 51 \\
\hline bGH & $60 \%$ & $75 \%$ & $99 \%$ & & 175 & 49 & 53 & 52 \\
\hline eGH & $60 \%$ & $74 \%$ & $91 \%$ & $92 \%$ & & 46 & 51 & 49 \\
\hline hPRL & $24 \%$ & $26 \%$ & $25 \%$ & $25 \%$ & $23 \%$ & & 143 & 156 \\
\hline oPRL & $27 \%$ & $28 \%$ & $26 \%$ & $27 \%$ & $26 \%$ & $72 \%$ & & 163 \\
\hline pPRL & $26 \%$ & $21 \%$ & $26 \%$ & $26 \%$ & $25 \%$ & $78 \%$ & $82 \%$ & \\
\hline \multicolumn{9}{|c|}{$\%$ of identity } \\
\hline
\end{tabular}




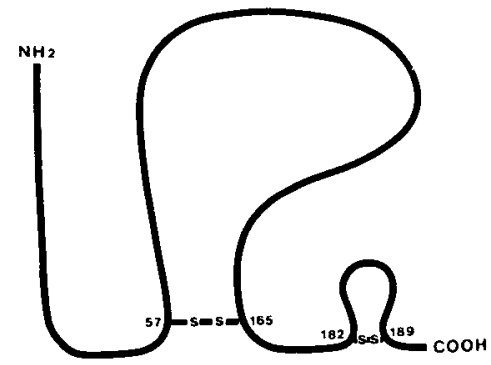

(a) $\mathrm{hGH}-22 \mathrm{~K}$

(C) $45 \mathrm{~K}$ dimers
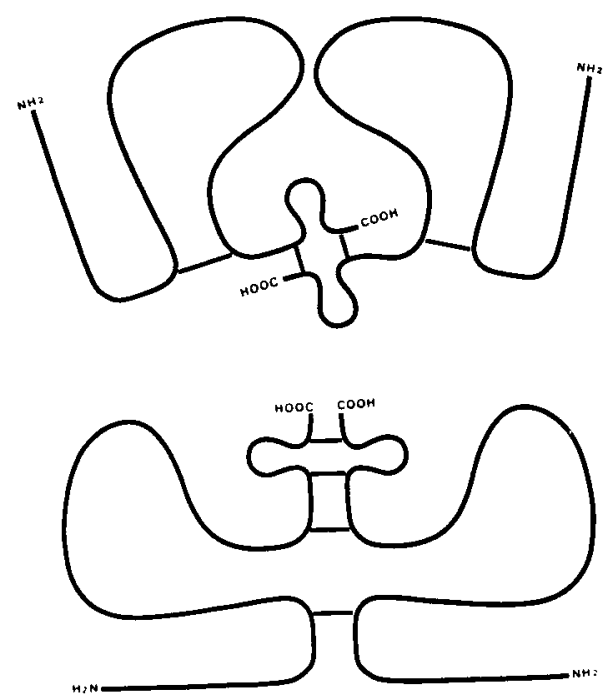

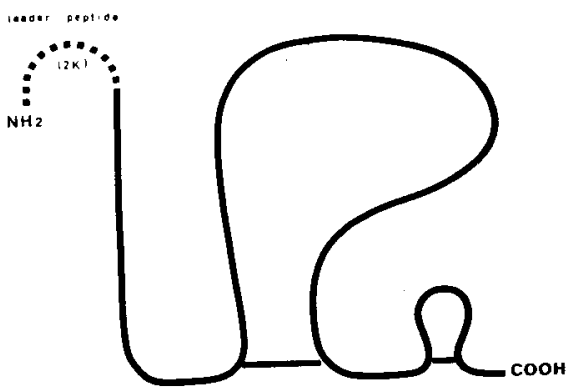

(b) pre-GH

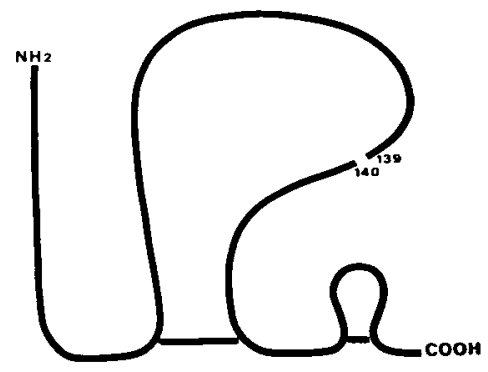

(d) $24 \mathrm{~K}$

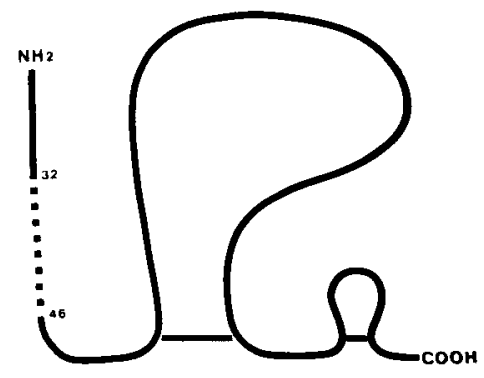

(e) $20 \mathrm{~K}$

FIG. 1. - Schematic representation of some mass variants of $h \mathrm{GH}$. a) major form, the 22000 dalton monomer, $b$ ) pre- $\mathrm{GH}$, with its leader peptide of $2 \mathrm{~K}$ at the $\mathrm{N}$-terminus, $c$ ) two among the possible configurations of the $45 \mathrm{~K}$ dimers, d) $24 \mathrm{~K}$ variant, a two chain form produced by a nick between AA 139 and 140 in the large loop, e) the $20 \mathrm{~K}$ variant, shortened by a deletion between AA 32 and 46. 
ment positions 14-46 (A), 58-98 (B), 114-139 (C) and 151-194 (D) in non mammalian GHs. The same authors suggest that domain $\mathrm{C}$ is responsible for specific $\mathrm{GH}$ bioactivity. However, since no single domain is associated with complete bioactivity (see part II on structure-function relationships), each of the conserved domains and the tertiary structure itself are thought to play an essential role in maintaining bioactivities. $\mathrm{GH}$ occupies a special place among the hypophyseal secretions: it is the only one that has no well-defined anatomical direct effector, and it accounts for about $10 \%$ of the dry weight of the gland (about $8 \mathrm{mg}$ for a human pituitary), that is one thousand-fold more than that of other hormones. The main biological activities of growth hormones (table 2) are the basis of the bioassays used to quantify them (table 3). Growth hormones are

\section{TABLE 2}

Biological effects of $h G H$ (from Chawla et al., 1983 (reproduced, with permission, from the Annu. Rev. Med., vol. 34, C 1983, by Annu. Rev. Inc.).

Metabolic

Physiologic

\author{
Stimulates amino acid transport \\ Stimulates protein synthesis in most cell types \\ Stimulates DNA/RNA synthesis in most cell types \\ Stimulates polyamine synthesis \\ Stimulates lipolysis \\ Inhibits insulin action on glucose metabolism
}

Anatomic

Increases renal blood flow, glomerular filtration rate, and tubular reabsorption of $\mathrm{PO}_{4}$

Increases basal metabolic rate

Stimulates new bone formation

Stimulates erythropoiesis

Expands extracellular fluid space

Accelerates linear growth

Reduces adipose mass and enlarges lean body mass (muscle, liver, kidney, heart, G. I. tract, pancreas, skeleton, connective tissue)

globular proteins, or rather polypeptides, of about 190 aminoacids (AA), whose secondary structure is almost entirely an $\alpha$ helix. Two disulfide bridges between AA 53-165 and 182-189 delineate, respectively, a large loop comprising $70 \%$ of the molecule and a small loop near the $\mathrm{C}$-terminal. However, this $\mathrm{GH}$ is not represented by only one molecular entity, but by a collection of parent molecules. Our purpose in this report is to recall the existence of these various forms that are generally called "variants» or sometimes « ioshormones». Part I will discuss the naturally occurring $\mathrm{GH}$ forms to the exclusion of forms deliberately and artefactually modified by a chemical or enzymatic process with a view to obtain a product with enhanced or suppressed activity. Such molecular modifications will be discussed in part II (Chêne et al., 1988) dealing with structure-function relationships. To abide by the recommendations of the "Commission on Biochemical Nomenclature ", we have used the term « variant " for factors whose differences arise from posttranslational modifications, and have reserved the term « isohormone» for factors whose differences are found at the gene level. 


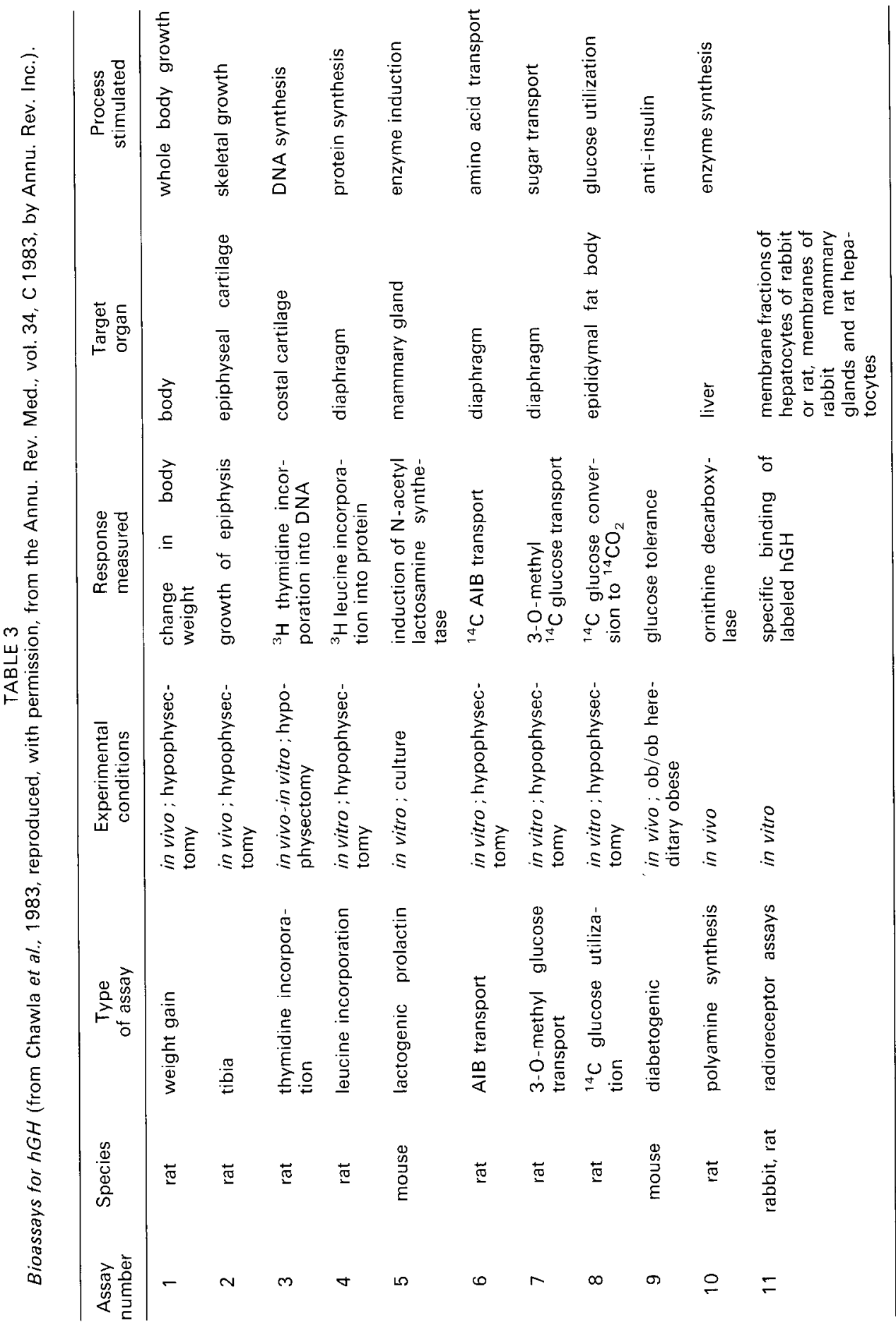


The existence of $\mathrm{GH}$ polymorphism is mainly attributable to the existence of charge variants and mass variants. This last category can be divided into two main types, aggregated and non-aggregated; these will be treated first in the pituitary and then in the plasma for didactic reasons. We have drawn a part of our information from Chawla et al. (1983) and we have used their classification. Afterwards, additional forms like bioinactive $\mathrm{hGH}$ or human placental $\mathrm{GH}$ will be considered. Most of the studies were done on human $\mathrm{GH}$. In the following chapters, we will discuss upon hGH heterogeneity, using it as a model. The outline of this discussion is found in table 4.

\section{Mass variants.}

\section{A. Aggregated forms.}

\section{a) In pituitary.}

1) Pre-hGH. - Pre-hGH is a 24,000 -dalton component corresponding to the addition of a small 2,000-dalton peptide on the Phe residue at the $\mathrm{N}$-terminus of the $22 \mathrm{~K}$ basal molecule (fig. 1b). Growth hormones are synthesized as pre-hormones. The conversion of pre-hGH to $\mathrm{hGH}$ involves the removal of this small peptide, called leader peptide or signal peptide, from the nascent hormone by a protease attached to the rough endoplasmic reticulum at the time of the secretion step. This may explain why this $24 \mathrm{~K}$ form is never found in plasma. Therefore the signal peptide plays a key role in the synthesis and secretion of a fully active hormone (Gaye et al., 1977 ; Lingappa and Blobel, 1980).

2) "Big " and " big-big " forms. - For many years, "big " and "big-big " forms, i.e. high molecular weight proteins, have been found by biochemists during the extraction/purification of $\mathrm{GHs}$ from plasma or pituitary extracts. For a time, "big " hGH was considered as a prohormone for hGH (pro-hGH) and «big-big » as a precursor for pro-hGH (pre-pro-hGh). Today, these appellations are no longer used. Is called « big-big » the form whose $\mathrm{MW}>45 \mathrm{~K}$ (Stolar et al., 1984) and which immunoreacts with an antibody directed against $\mathrm{hGH}$. The " big » and "big-big » GH would be actually arbitrary distinctions of a series of oligomers up to the pentamer form. The reported proportions of these oligomers relative to total $\mathrm{GH}$ vary according to the authors, starting material and methods used [gel filtration on Sephadex, polyacrylamide gel electrophoresis (PAGE) with or without sodium dodecyl sulfate (SDS), a denaturing detergent]. Thus, Frohman et al. (1972), starting from fresh pituitaries, isolated a $45 \mathrm{~K}$ form on $\mathrm{G} 75$ Sephadex that they estimated accounted for about $1 \%$ of the total immunoreactivity. Treated with guanidine, $80 \%$ of this variant was dissociated into monomers. Benveniste et al. (1975) succeeded in converting all the $45 \mathrm{~K}$ material into $22 \mathrm{~K}$ components by mercaptoethanol and urea treatment. They concluded that $60 \%$ of the dimers were attributable to interchain disulfide bridges, the remaining $40 \%$ being non-covalent dimers (fig. 1c). Starting from previously purified hGH, 
TABLE 4

The growth hormone variants will be described according to this framework.

MASS VARIANTS

Pituitary

Aggregated forms

Plasma

Plasma

$24 \mathrm{~K}$

$20 \mathrm{~K}$
Pituitary

$24 \mathrm{~K}$

$20 \mathrm{~K}$

Non aggregated forms
$80 \mathrm{~K}$ forms

pre-GH (24 K)

Big and Big-big

$45 \mathrm{~K} \&$ oligomers

* $80 \mathrm{~K}$

* $80 \mathrm{~K}$ complexe

CHARGE VARIANTS

Two-chain forms

$$
\begin{aligned}
& { }^{*} B, C, D, E \\
& { }^{*} \alpha 2 \text { and } \alpha 3
\end{aligned}
$$

Fast hGH (N-acetylated)

Slow hGH (alklin forms)

Deamidated forms

a and $\mathrm{c}$ forms

Glycosylated $\mathrm{GH}$

Phosphorylated GH

OTHER VARIANTS

Bio inactive $\mathrm{hGH}$

SV-gGH-2

$17.5 \mathrm{~K}-\mathrm{hGH}$

Human Placental

$\mathrm{GH}$ (hPGH)

Lewis et al. (1977) confirmed the results of Benveniste and specified the biological and immunochemical characteristics of the $45 \mathrm{~K}$ variant : compared to the standard $22 \mathrm{~K}$ monomer, it was only $10-15 \%$ as active in the weight gain assay, about $50 \%$ as active in the crop sac assay (lactogenic activity) and about $50 \%$ as active in antibody binding. This immunoreactivity was even estimated as not over $10 \%$ by Sigel et al. (1980). It is likely that antibodies in classical RIA are not able to accurately recognize dimers. 
b) In plasma.

According to Stolar and Baumann (1986), circulating aggregates appear to originate from pituitary stores rather than from aggregation in the blood stream. This assertion does not completely fit recent data and will be discussed later (cf. "Physiological relevance of mass variants", p. 868).

1) Oligomers and $45 K$ dimers. - Aggregated forms in plasma are quite similar to those described in the pituitary. But they could represent from 15 to $50 \%$ of total plasma immunoreactivity, a much higher proportion than in the pituitary (Benveniste et al., 1975 ; Lewis et al., 1977 ; Stolar et al., 1984) or in pituitary tissue culture media (Guyda, 1975; Skyler et al., 1977). Like in the pituitary, the plasma aggregated forms are distributed according to two types of aggregates: 1) about $70 \%$ are relatively labile and easily converted into $22 \mathrm{~K}$ monomers during extraction; they are likely due to non-covalent binding, 2) the remaining $30 \%$ are resistent to $1 \%$ boiling SDS and only disulfide reduction dissociates them into $22 \mathrm{~K}$ monomers (Stolar et al., 1984). It must be noted that the conversion of « big » hGH into monomers gives rise to much more $20 \mathrm{~K}$ variant (see below) than predicted from its usual proportions. The strong propensity of $20 \mathrm{~K}$ to aggregate may explain this observation.

The bioactivity of the "big » form, assayed on human lymphocyte or rabbit hepatocyte receptors, was only 26 to $40 \%$ of that of the $22 \mathrm{~K}$ monomer (Soman and Goodman, 1977). Other kinds of bioactivity were not determined, but its immunoreactivity towards antibodies raised against $22 \mathrm{~K}$ was equipotent with that of the monomer. This fact constitutes a striking contradiction with the low immunoreactivity of pituitary « big " forms (Lewis et al., 1977 ; Sigel et al., 1980).

2) $80 \mathrm{~K}$ forms.

(i) $80 \mathrm{~K}$ variant. - Ellis et al.(1978) reported a « big " variant different from those mentioned above. These authors were intrigued by the discovery that plasma GH bioactivities, as assayed by the tibia line, were discrepant from the RIA values (Ellis et al., 1976). The ratio between bioactivity and RIA activity ranged from 50 to 200 (by definition this ratio is 1 for the $22 \mathrm{~K}$ reference). They succeeded in isolating a variant of about $80 \mathrm{~K}$ molecular weight for which the tibia/RIA ratio was more than 100 . This acidic material $(\mathrm{pH} 5)$ was not studied further. However, it could account for more than $80 \%$ of plasma «tibial» bioactivity!

A similar $80 \mathrm{~K}$ form, also found in rat plasma, had a tibia/RIA ratio of the same order of magnitude as human $80 \mathrm{~K}$ (Ellis et al., 1978). Though this $80 \mathrm{~K}$ variant has not been identified in pituitary, its jugular vein concentration is about three times higher than in the aorta.

(ii) The $80 \mathrm{~K}$ complex. - The eventuality of $\mathrm{hGH}$ binding to a plasma protein has been often considered in the past but never evidenced. As early as 1977 , Beitins et al. discovered that ${ }^{131} \mathrm{I}-\mathrm{hGH}$ injected in vivo or added in vitro to plasma gave rise, $10 \mathrm{~min}$ later, to radiolabeled «big » forms. These newly radiolabeled «big » forms, were due either to dimerisation or to binding to a plasma protein, 
which is neither an albumin nor a globulin. The Australian group of Herington recently showed that rabbit serum possesses a protein of about 100,000 molecular weight which specifically binds human and bovine GHs (Ymer and Herington, 1985). This protein is totally soluble, passes through $0.22-\mu \mathrm{m}$ Millipore filter, does not sediment at $200,000 \times \mathrm{g}$ and does not precipitate with polyethylene-glycol. Such a protein was also found in normal sheep serum, but not in serum from male rats (Ymer and Herington, 1985).

More recently, a similar protein was demonstrated in human species simultaneously by Baumann and co-workers in Chicago and by the Herington group in Melbourne. Baumann et al. (1985a) characterized a protein in human plasma which specifically binds the $22 \mathrm{~K}$ variant and more weakly the $20 \mathrm{~K}$ variant. This protein is neither an albumin nor an immunoglobulin; by gel filtration on G-100 Sephadex it has a 60-70 K MW, and with hGH it gives a 80-85 K complex. It has a high affinity $\left(\mathrm{Ka}=2-3 \times 10^{8} \mathrm{M}^{-1}\right)$, limited capacity (20 ng $\mathrm{hGH} / \mathrm{ml}$ ), high specificity (it does not bind hPL, hPRL or $\mathrm{rGH}$ ) and binding reversibility. All these criteria are characteristic of a binding protein. The association of hGH with the binding protein at a stoichiometric ratio of 1 mole $\mathrm{hGH} /$ mole $\mathrm{BP}$ is rapid at $37^{\circ} \mathrm{C}$, and $75-80 \%$ of maximal binding is reached after $5 \mathrm{~min}$ (Baumann, 1987). The source of this protein is not known, but it is probably not of pituitary origin since it occurs in hypopituitary dwarfs. In physiological conditions, 15 to $18 \%$ of the circulating hGH would be in this form and could represent a fraction of the «big-big » $\mathrm{GH}$. Its affinity for hGH however is lower than that of the $\mathrm{GH}$ receptor. According to Baumann (1987), binding proteins exist in two different forms, a major one of $61,000 \mathrm{MW}$, responsible for about $80-85 \%$ of the circulating hGH binding, and another one with a MW of about 100,000 daltons. Under basal conditions and up to levels of $20 \mathrm{ng} / \mathrm{ml}$, about $50 \%$ of $22 \mathrm{~K}$ and $30 \%$ of $20 \mathrm{~K}$ exist in complexed form. It is likely that Herington et al. (1986) isolated the same protein from human sera, with the same high affinity for $\mathrm{hGH}\left(\mathrm{Ka}=3.10^{8} \mathrm{M}^{-1}\right)$, about $1 / 3$ to $1 / 5$ that of $\mathrm{GH}$ receptors, and a binding capacity of $1840 \mathrm{fmol} /$ serum $\mathrm{ml}$. $\mathrm{GH}$ binding, dependent on time, temperature, and serum concentration, is completely reversible and the complex would have a molecular weight of about 74-85,000 daltons, as shown by gel filtration on Ultrogel AcA 34. The molecular weight differences observed between the two groups could result from the different chromatographic systems used for their determination. From the point of view of specificity, this protein does not bind other hormones of human origin (hPRL, hPL) or GHs and PRLs from other species (bGH, oGH, oPRL). The authors estimate that 30 to $40 \%$ of the $\mathrm{GH}$ in normal serum may be in this bound form.

According to Silverlight et al. (1985), plasma $\mathrm{rGH}$ in female rats could circulate almost completely in $82 \mathrm{~K}$ form, whereas in males more than $65 \%$ is found as a monomer. In adenohypophysis of both sexes $\mathrm{rGH}$ is almost exclusively found in the monomer form. The authors ascribe this difference between male and female rats to the presence of a binding protein in the circulation, whose synthesis would be sex-dependent.

The possible physiological relevance of the various bound forms will be discussed later (cf. "Physiological relevance of mass variants", p. 868). 


\section{B. Non-aggregated forms.}

a) In pituitary.

1) The $24 K$ variant. - Except for a break in the chain within the large disulfide loop (probably of proteolytic origin), between residues Phe 139 and Lys 140 , the $24 \mathrm{~K}$ variant is identical to the $22 \mathrm{~K}$. The break converts the molecule into a two-chain form (fig. 1). Its migration features on SDS-PAGE are modified, the Stokes radius enlarged and, hence, its apparent molecular weight is increased (Singh et al., 1974a).

Compared to the $22 \mathrm{~K}$ variant, the $24 \mathrm{~K}$ one retains its full immunological and growth-promoting activities (Lewis et al., 1980b) and has enhanced lactogenic activity (Chawla et al., 1983).

This $24 \mathrm{~K}$ variant must not be confused with pituitary pre-GH (see above) whose MW is also $24 \mathrm{Kd}$.

2) The $20 \mathrm{~K}$ variant. - The $20 \mathrm{~K}$ form is probably the most important variant of $22 \mathrm{~K}-\mathrm{hGH}$. It accounts for $10-15 \%$ of the total pituitary store of hGH (Lewis et al., 1978) and up to $20 \%$ of the GHs released in a pituitary cell culture medium after 24-hour incubation (Markoff et al., 1986). According to Lewis et al. (1980a), it differs from the basic $22 \mathrm{~K}$ by a deletion of 15 amino-acids (residues 32 to 46) (fig. 1). This deletion does not result from the posttranscriptional processing of mRNA. The hGH-N gene (normal gene encoding for $22 \mathrm{~K}-\mathrm{hGH}$ ) contains an alternate splice point (designated $\mathrm{B}^{\prime}$ in fig. 2). Wallis (1980) and de Noto et al. (1981) suggested that $20 \mathrm{~K}$ with its $32-46$ deletion might arise from a splicing of the pre-GH messenger precursor RNA at this point. The determinism which prompts the pituitary to synthesize $22 \mathrm{~K}$ rather than $20 \mathrm{~K}$ (or vice-versa) is still unknown. Still recently it was thought that the synthesis of both forms was controlled by different GRFs (since GRF 1-44- $\mathrm{NH}_{2}, \mathrm{GRF} 1-40-\mathrm{OH}$ and GRF $1-37-\mathrm{NH}_{2}$ were found in hypothalamus) and that they themselves were controlled by specific metabolic needs. However, Baumann and Stolar (1986) have reported that a series of classical stimuli inducing a $\mathrm{GH}$ release, as specific as $\mathrm{GRF}$ $(1-40)$ or more generally acting as exercise, result in the same relative proportions of three monomeric forms : $22 \mathrm{~K}$ (about $76 \%$ ), $20 \mathrm{~K}$ (about $16 \%$ ), acidic forms (about $8 \%$ ) which were not structurally identified. No significant differences were noted between men and women or between normal and acromegalic patients. These authors concluded that the release of individual $\mathrm{hGH}$ forms was not stimulus-specific.

With RIA the $20 \mathrm{~K}$ variant was only $30-35 \%$ as active as the $22 \mathrm{~K}$ form (Lewis et al., 1978). On the other hand, it has been reported to have growth-promoting activity in hypophysectomized rats and lactogenic activity in the pigeon crop assay equivalent to those of $22 \mathrm{~K}$ (Lewis et al., 1978 ; Closset et al., 1983), and the same somatomedin-generating potency in vivo (Spencer et al., 1981). In other bioassays, however, shortening the $\mathrm{N}$-terminal portion of the molecule caused noticeable changes in biological activity. The $20 \mathrm{~K}$ variant was reported to lack the early insulin-like effect $(1 \mathrm{~h}$ ) of $22 \mathrm{~K}$ (hypoglycemia and decrease in serum FFA), the late rise ( $5 \mathrm{~h}$ ) in serum FFA, the glucose uptake in the fat pad and 


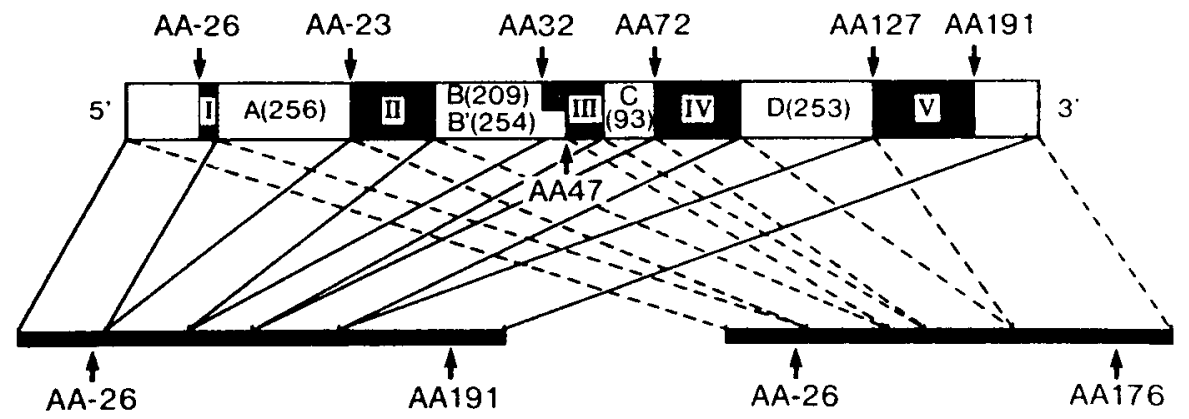

Pre $22 \mathrm{k} \mathrm{hgH} \mathrm{m} \mathrm{RNA}$

Pre $20 \mathrm{khgH}$ m RNA

Scale $\stackrel{100 \text { bp }}{\longleftarrow}$

FIG. 2. - Theoretical representation of the $h G H$ gene and the mRNA transcripted from it. The hGH gene contains three introns : intron $A$ in the sequence of pre- $\mathrm{GH}$, intron $B$ between $A A 31$ and 32 , and intron $C$ between $A A 71$ and 72. Note the alternate splice point B' at AA 47 (see text). These introns are excised out when the gene is transcripted into the mRNA for the hormone (from Chawla et al., 1983, reproduced with permission from the Annu. Rev. Med., vol. 34, C, 1983, by Annu. Rev. Inc.).

the diabetogenic effect in dogs (Frigeri et al., 1979; Lewis et al., 1981b). Moreover, in RRA using plasma membrane receptors from both pregnant rabbits and normal female rats (somatotropic receptors) or mammary gland receptors of pregnant rabbits (lactogenic receptors), specific binding was only $3-20 \%$ and $22-53 \%$, respectively, as effective as with $22 \mathrm{~K}$ (Sigel et al., 1981). These findings suggest that $20 \mathrm{~K}$ and $22 \mathrm{~K}$ may have separate receptors in target cells though they were shown to have a similar affinity for both kinds of liver and mammary gland receptors from pregnant rabbits (Closset et al., 1983). A recent work of Smal et al. (1986) using isolated rat adipocytes (a target for the insulin-like effects of GH) and cultured IM-9 human lymphocytes (more specific for growth effects) shows that $20 \mathrm{~K}$ is a potent agonist of $22 \mathrm{~K}$ in the lymphocyte assay, while its potency in the adipocyte is only $3 \%$. In receptors from pregnant rabbit liver, $20 \mathrm{~K}$ also behaves like $22 \mathrm{~K}$ (Smal et al., 1987). Thus the receptors for hGH appear to be different in various tissues. Those of IM-9 human lymphocytes and rabbit liver can bind both $22 \mathrm{~K}$ and $20 \mathrm{~K}$, while those of adipocytes poorly recognize the $20 \mathrm{~K}$ variant hence depriving the $20 \mathrm{~K}$ variant of any insulin-like effect. The recent data of Kostyo et al. (1985) and Tinsley et al. (1986) show that the Met-20 K variant, obtained from recombinant DNA techniques in $E$. coli, has substantial diabetogenic and insulin-like activities but that the doses required to obtain activity are higher than with $22 \mathrm{~K}$. It can thus be inferred that the deletion region 32-46 has a role in the full expression of the activity, either because it contains a portion of the active site for this property or because it alters the conformation of the $20 \mathrm{~K}$ molecule. However, in respect to the doses used by the different authors, such apparently controversial results are not necessarily discrepant. 
b) In plasma.

The $24 \mathrm{~K}$ variant described by Lewis in the pituitary has not been detected in plasma yet, perhaps because of its low concentration or the lack of recognition of the antibodies not specifically directed against it.

The circulating $20 \mathrm{~K}$ material accounts for $5-15 \%$ of total $\mathrm{GH}$ immunoreactivity, which agrees with its relative proportion in the pituitary gland. Baumann et al. (1985b) found that the $20 \mathrm{~K}$ and $22 \mathrm{~K}$ variants had similar distribution volumes, corresponding about to the extracellular fluid space, but the metabolic clearance rate of $20 \mathrm{~K}$ was 2 to 3 -fold lower than that of $22 \mathrm{~K}$.

\section{Physiological relevance of mass variants.}

In this chapter, we will focus on the qualitative and quantitative importance of $\mathrm{GH}$ mass variants and discuss their physiological implications.

\section{a) GH production in vitro.}

The analysis of $\mathrm{GH}$ production in cell cultures provides a means of knowing which forms are synthesized. The secretion product of normal human pituitary glands, or of acromegalic pituitaries maintained in organ culture, was examined by Baumann and Mac Cart (1982) using polyacrylamide gel electrophoresis and electrofocusing. They found that pituitary secretes primarily the $22 \mathrm{~K}$ variant. Other forms, if secreted, were below the detection threshold of the method. However, using a combination of SDS-PAGE and immunoblotting. Markoff et al. (1986) succeeded in producing both the $22 \mathrm{~K}$ and the $20 \mathrm{~K}$ variants in human pituitary cells cultured for 16 days. Under basal conditions, the cells released $2.8 \mu \mathrm{g}$ of $\mathrm{hGH}-22 \mathrm{~K} / \mathrm{ml}$ and $0.7 \mu \mathrm{g}$ of $\mathrm{hGH}-20 \mathrm{~K} / \mathrm{ml}$ of medium per day. $\mathrm{GHRH}$ treatment $\left(10^{-8} \mathrm{M}\right)$ resulted in a stimulation of both variants in the same respective proportions. Curiously, the $20 \mathrm{~K} / 22 \mathrm{~K}$ ratio increased with time from $1 / 19$ in the first hour of incubation to $1 / 4$ by $24 \mathrm{~h}$. Whatever the conditions, secreted hGH appeared essentially as monomers. Thus, in vitro-produced hGH appears to be more homogeneous than the hGH present in most pituitary extracts. Identical observations were made in vivo with $\mathrm{GH}$ peaks obtained with secretagogues (CAMP or prostaglandin E2) or from acromegalic tissue, which were qualitatively indistinguishable from normal spontaneous $\mathrm{hGH}$ (Baumann and Mac Cart, 1982).

On the contrary, about 40 rat immunoreactive proteins were seen by 2 D-PAGE analysis of cell-free translation products of mRNA derived from male rat pituitary cells in monolayer culture (Yokoya and Friesen, 1986). Among them, 16 proteins had a molecular weight of 22,000 daltons or less. The release of most of them was either stimulated or inhibited by hGRF and somatostatin, respectively. These findings suggest that rat $\mathrm{GH}$ has a lot of variants.

\section{b) GH species in vivo.}

In mouse serum, $\mathrm{GH}$ was reported to be present in "big " and " little » forms (Sinha, 1980). In 15-day old animals the « little» form was the major constituent, 
while at 80 days of age the « big " form was predominant. Thus larger forms of $\mathrm{GH}$ are considered by the author as natural entities, resulting mostly from postsecretional transformations in the systemic circulation. He suggested that the "big " $\mathrm{GH}$ represent minipackets of hormones designed to facilitate hormone transport and action at the level of target tissues.

In man, we have already noted the high proportion (15-50\%) of total immunoreactive $\mathrm{GH}$ of «big » hGH forms in plasma. Gel profiles on SDS-PAGE indicated that two-thirds of these «big " forms were non-covalently aggregated and easily converted into " little " forms. The remaining third could be converted almost completely into monomeric forms by sulfhydril reduction of the bridges (Stolar et al., 1984). The « little " forms consist essentially of monomers, of which $22 \mathrm{~K}$ is the major variant (about 76 to $85 \%$ ), followed by $20 \mathrm{~K}$ (about 7 to $16 \%$ ) and the more acidic forms: $\mathrm{N}$-acetylated, deaminated, or cleaved chains (5-10\%). Growth hormone collected from spontaneous bursts or after physiological stimuli such as excercise, or pharmacological stimuli as L-DOPA, GRF, estrogens or $\mathrm{TRH}$, resulted in the same electrophoretic patterns and the same relative proportions in both sexes and in acromegalics (Baumann et al., 1983; Stolar et al., 1984 ; Baumann et al., 1985a ; Baumann and Stolar, 1986; Markoff et al., 1986). Thus, the release of pituitary $\mathrm{hGH}$ variants is not stimulus-specific. In contrast, plasma hGH patterns during basal periods were much more variable and, besides the usual variants, included immunoreactive components with molecular weights of $30 \mathrm{~K}, 16 \mathrm{~K}$ and $12 \mathrm{~K}$ which were consistently identified. Their relative preponderance differed greatly from one subject to another. Such hGH fragments, not reported before, could represent a dominant part of the total immunoreactivity in the basal state (Baumann et al., 1985a). The same relative proportions of major forms found in plasma were also reported in human urine (Baumann and Abramson, 1983). Indeed, urinary hGH is presumed to reflect the pattern of plasma hGH. However, only a minute fraction ( $<0.01 \%)$ of the $h \mathrm{GH}$ secreted clears through the kidneys which do not seem to be responsible for any interconversion among the hGH forms.

The discrepancy between the full growth-promoting and somatomedingenerating (Lewis et al., 1978; Spencer et al., 1981) potency in vivo of the $\mathrm{hGH}-20 \mathrm{~K}$ variant, as compared to $22 \mathrm{~K}$, and its poor binding interaction on $22 \mathrm{~K}$ receptors in a variety of tissues (Sigel et al., 1981 ; Wohnlich and Moore, 1982 ; Smal et al. 1986) has been emphasized above. One possible mechanism explaining normal bioactivity in vivo, despite low receptor binding, could be the more prolonged persistence of the $20 \mathrm{~K}$ variant in the blood stream. Some years ago, after injecting hGH material from U. J. Lewis into mice, Sigel et al. (1982) failed to discriminate different half-life values for hGH and the $20 \mathrm{~K}$ variant. However, the above-mentioned hypothesis was verified by the team of Baumann (1985b) who found that the metabolic clearance rate (MCR) of hGH-20 K injected into rats was 2 to 3 -fold lower than that of $22 \mathrm{~K}$. Furthermore, the MCRs of the dimers of each of them were significantly lower than those of the corresponding monomers ( 5 -fold in the case of hGH-22 K and 2-fold in the case of $\mathrm{hGH}-20 \mathrm{~K}$ ). Both dimers were also degraded at slower rates than the 
monomers (Baumann et al., 1986b). These observations may account for the relative preponderance of large molecular weight $\mathrm{GH}$ forms in blood as compared to pituitary.

The findings of Hendricks et al. (1985) constitute a leap forward in the understanding of the mechanisms by which the «big » forms occur. These authors injected hGH as bolus into euthyroid hypopituitary patients; blood samples were collected from 5 to $180 \mathrm{~min}$ after the injection and the plasmas were gel-filtered on Sephadex G-100. Figure 3 shows the interconversion which occurred from
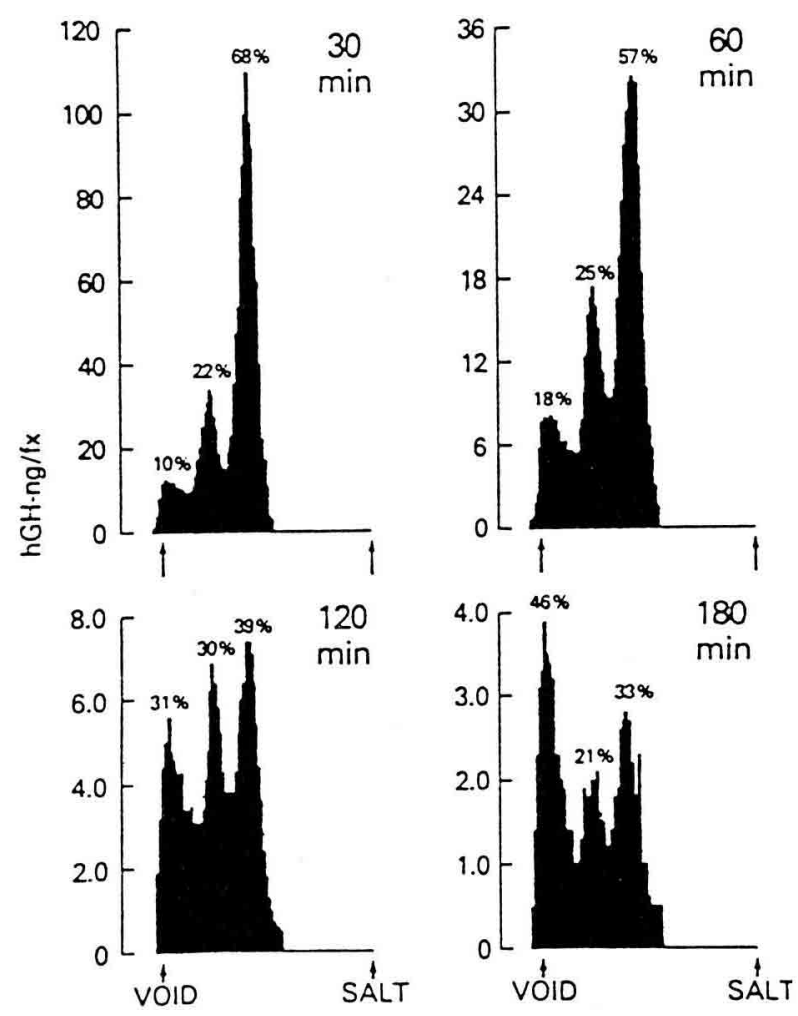

FIG. 3. - Sephadex G-100 patterns showing changing percentages of hGH components as the sampling time interval increased after iv hGH injection in hypopituitary patients. Left arrow marks the void volume and the beginning of the least retarted (pre-big) hGH peak, followed by the big $\mathrm{hGH}$ component and then the major peak of little $\mathrm{hGH}$. Right arrow denotes the salt elution. Percentages were calculated from pooled fraction values within a given peak divided by the sum of all fractions measured. The longest sampling from the injection time (180 min) contains a significantly lower percentage of the little, most biologically active hGH component (from Hendricks et al., 1985, with permission). 
« little» forms to «big » ones as a function of the time elapsed. The longer the time after initial hGH injection, the larger the percentage of the bigger $\mathrm{hGH}$ component, and the larger the component, the longer it took to be cleared from the plasma (fig. 4). The data of Nixon and Jordan (1986) who studied GH in

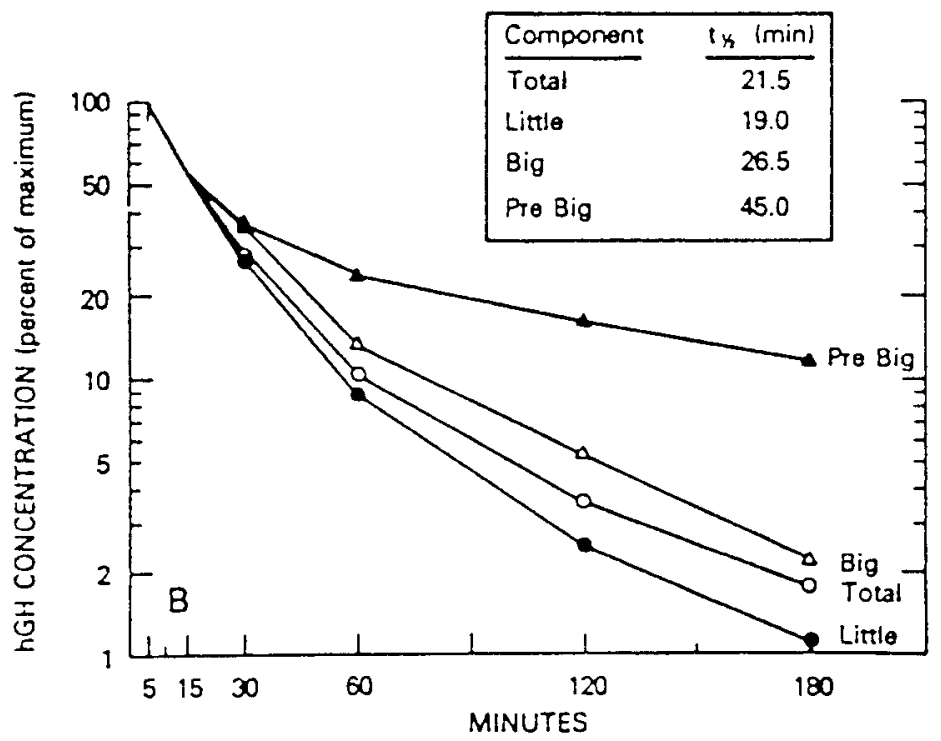

FIG. 4. - Clearance of $h G H$ components. The data plotted are the mean concentrations (nanograms per $\mathrm{ml}$ ) of total $\mathrm{hGH}$ and its components at each time point for two studies. For these, the 5 min mean hGH concentration was plotted as $100 \%$. Component concentration : total hGH concentration $\times$ percentage of the component, as determined by gel filtration, as shown in fig. 3 . Insert : half-live (t $1 / 2$ ) for each $h \mathrm{GH}$ component. The $\mathrm{t} 1 / 2$ represents the time required for $50 \%$ reduction of mean $\mathrm{hGH}$ (from six studies) using the concentration at $30 \mathrm{~min}$ as the initial reference point (from Hendricks et al., 1985, with permission).

human cerebrospinal fluid (CSF) strengthen this concept. In CSF, a biological fluid largely isolated from serum proteins, virtually all the GH (more than $97 \%$ ) occurred in monomeric form, whereas the large component comprised more than $15 \%$ of the total immunoreactivity in simultaneously-obtained serum. When monomeric hGH extracted from CSF was incubated with serum, $16 \%$ of the immunoreactivity eluted in the "big" material region (fig. 5). Thus the in vitro events reproduced in vivo observations already made by Hendricks et al. (1985). Moreover, as did Hendricks et al., Nixon and Jordan observed that the binding of hGH to serum proteins was time-dependent (fig. 5).

The physiological role of such binding has not been determined to date. However, some recent results on the biological effects of the full complex $\mathrm{hGH}$-antibody evoke troubling analogies and raise questions. Monoclonal antibodies to $\mathrm{hGH}$ and $\mathrm{bGH}$ are able to potentiate the actions of these hormones 


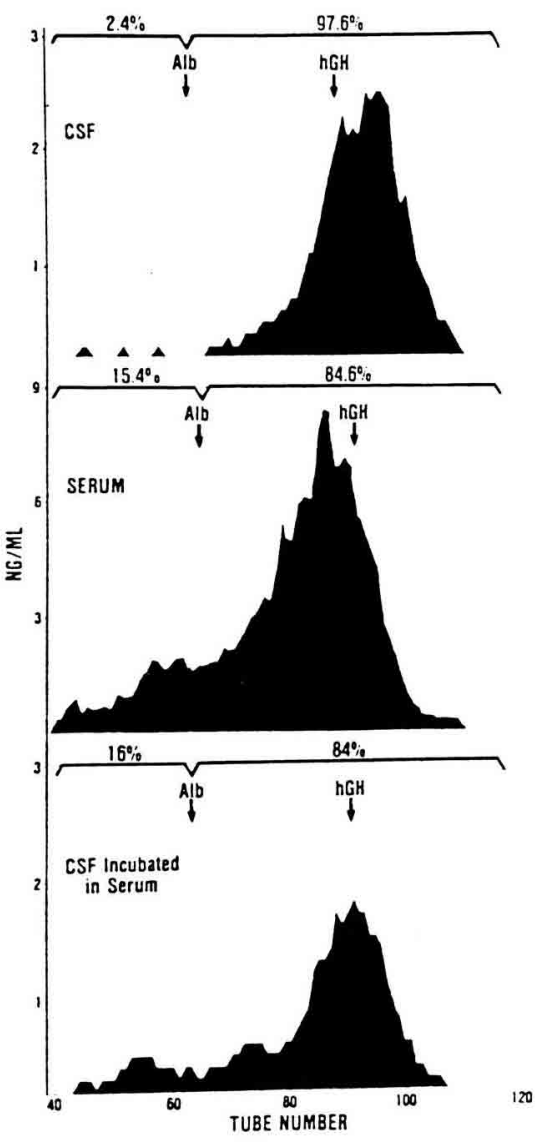

A

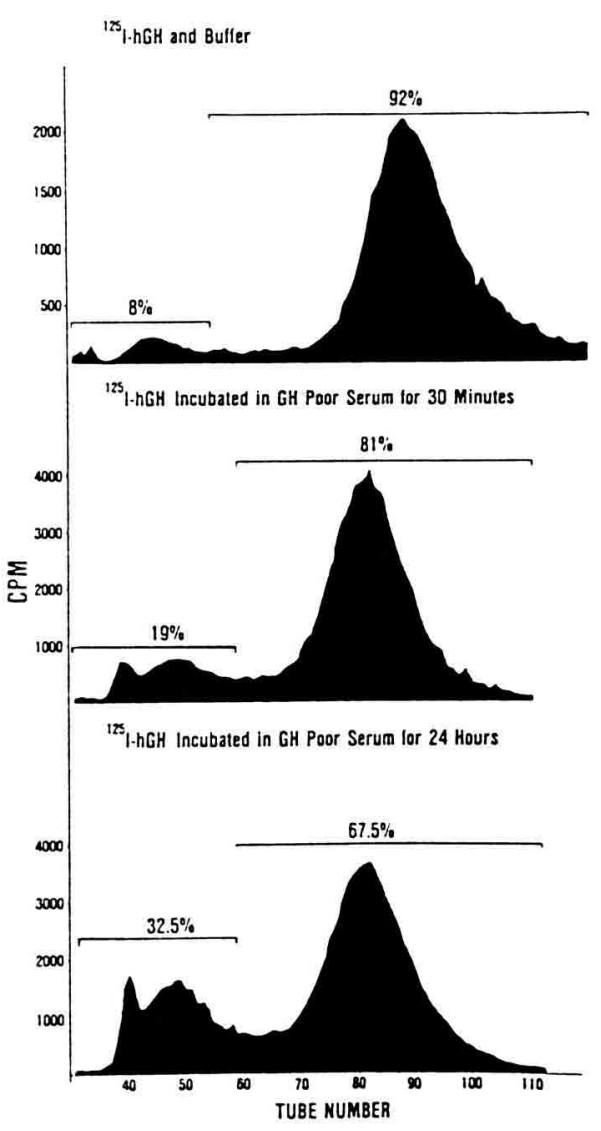

B

FIG. 5. - Elution patterns on Sephadex G-100 chromatography.

A) The elution pattern of human cerebrospinal fluid (CSF) (top panel), serum (middle panel) and CSF incubated in growth hormone-poor serum (bottom panel). The addition of growth hormone-poor serum changed the elution pattern causing the appearance of large molecular weight species. Arrows show elution position of added radioactive markers.

B) ${ }^{125} \mathrm{I}-\mathrm{GH}$ after $30 \mathrm{~min}$ of incubation with phosphate-buffered saline (upper panel), $30 \mathrm{~min}$ (middle panel) and $24 \mathrm{~h}$ (lower panel) of incubation with growth hormone-poor serum (from Nixon and Jordan, 1986, with permission of Acta Endocrinologica).

on growth and on sulfation of cartilage in hypopituitary dwarf mice and hypophysectomized male rats (Aston et al., 1986); they can even increase the effective potency of $\mathrm{hGH}$ by at least 25 -fold in the $\mathrm{SM}-\mathrm{C}$ generation in hypox rats (Wallis and Aston, 1987). Thus, in the same manner as IGF-binding protein complexes are supposed to constitute a hormone reservoir and increase IGF half-life in the circulation, the binding of hGH on specific binding proteins or 
monoclonal antibodies could lead to a slower elimination rate of growth hormone, rendering it more available to tissues. Such a mechanism would supply low, but constant, levels of the hormone to its target cells, thus better stimulating cell growth than if applied in high but temporary concentrations. If enhancement of the biological effectiveness of $\mathrm{GH}$ by binding on antibodies is confirmed by further experiments, it could be of great interest in both human clinical use and animal breeding and meat production. However, long-term treatments with such artificial protein complexes are likely to rapidly give rise to immunological refractoriness.

In conclusion, it now appears that in fanned-out mass variants of $\mathrm{GH}$, monomeric $22 \mathrm{~K}$ occupies the main place, followed by $20 \mathrm{~K}$. Both are able to aggregate (especially $20 \mathrm{~K}$ ) to form dimers and oligomers up to pentamers in the pituitary as well as in the blood stream. Most are held together by non-covalent bonds and the remaining are connected by disulfide bridges. In serum they both tend to bind to proteins to form large complexes which, in turn, presumably represent an important part of the «big-big" forms.

\section{Charge variants of $\mathrm{GH}$.}

The majority of charge variants were identified from various extracted and purified preparations of pituitary hGH. Few of them were found in plasma, except for acidic $\mathrm{GH}$, like $\mathrm{N}$-acetylated or deaminated forms which are systematically reported to accompany $22 \mathrm{~K}$ and $20 \mathrm{~K}$ monomers.

1) Two-chain forms. - In 1973, Chrambach and co-workers, using a PAGE system, isolated a series of hGH variants (labeled B, C, D, E) of the same molecular weight but showing a progressive increase in electric charge from $B$ (basic), the major component, to $E$ (acid). Variants $C, D$ and $E$ could result from the progressive digestion of B with plasmin (Chawla et al., 1983). According to Lewis and Cheever (1965), all preparations of hGH might be contaminated with a proteinase. If plasmin was such a proteinase inherent in Chrambach's preparation, the conversion from $B$ to $E$ forms might be explained. The four variants were identical in RIA. But interestingly, the growth-promoting, lactogenic and somatomedin-generating activities of the more acidic forms, $D$ and $E$, were 3 to 8 -fold as potent as B (Yadley et al., 1973). Plasmin is known to cleave the large disulfide loop in the region 136-140 (Baumann and Nissley, 1979). Such a cleavage, which can involve a single nick or removal of a short peptide sequence, converts the single-chain molecule into a two-chain structure. Secondary and tertiary structures are modified by this change. The metabolic clearance rate is significantly lowered, which might at least partially account for its enhanced biological activity (Baumann, 1976).

Nearly at the same time, Lewis et al. also characterized four charge variants from extracts of human pituitary gland (Singh et al., 1974b ; Lewis et al., 1976). These forms, designated $\alpha_{1}, \alpha_{2}, \alpha_{3}$ and $\beta$, appear to be electrophoretically similar to the four forms B, C, D and E studied by Chrambach et al. Among these, $\alpha_{2}$ and $\alpha_{3}$, which were shown to lack sequences 135-140 and 135-146, respectively, 
seem to be the more interesting. Like the B to $E$ series, all the Lewis-modified forms were indistinguishable from the intact hormone by RIA. By tibial and lactogenic assays, $\alpha_{3}$ was 5 and 10 -fold, respectively, more active than native hGH.

The cleaved form of $\mathrm{hGH}$, isolated from the pituitary and that had growthpromoting activity, was found in only small amounts in the pituitary (Lewis et al., $1980 \mathrm{~b})$. Whether these charge isomers are actually in the pituirary or the blood is still uncertain. They were purified from pituitaries collected several hours after the death of the patients and thus long enough to allow the internal proteases to work. But none of the proteases tested in vitro degraded $\mathrm{hGH}$ in the way needed to obtain $\alpha_{3}$. Nevertheless, Chrambach's isomers were also isolated from the tissue culture of a pituitary adenoma (Kohler et al., 1971). All these two-chain variants, if present in plasma, could be produced by proteolytic plasmin-like cleavage at the time of secretion and thus might have physiological importance. Furthermore, Lewis et al. have detected a peptide in blood, corresponding to the deletion peptide residues 132-146 of hGH (Chawla et al., 1983).

2) Fast $G H$. - In electrophoresis a minor component migrates just before the $22 \mathrm{~K}$ front and therefore is more acidic and more rapid. It was termed " fast hGH » (Lewis et al., 1979). After isolation on DEAE-cellulose, structure analysis indicated that the $\mathrm{N}$-terminal phenylalanine was blocked by an acetyl (Lewis et al., 1980b). This $\mathrm{N}$-acetylated $\mathrm{hGH}$ is equipotent with $22 \mathrm{~K}$ in the tibial assay line and in RIA as well. Lewis et al. (1980b) estimated that fast GH accounts for about $5 \%$ of the growth hormone in pituitary gland.

3) Deamidated forms. - The group of Lewis also reported two desamido forms of $h \mathrm{GH}$ resulting from the deamidation of AsN-152 and GIN-137 (Lewis et al., 1981a). Their bioactivities were not reported, but their immunoreactivity in RIA was half that of the $22 \mathrm{~K}$ variant.

4) Slow hGH-alkaline forms. - Another type of heterogeneity was described by Lewis et al. (1979) when they incorporated urea in the electrophoresis gel system. They observed two components which migrated more slowly than the major form of $\mathrm{hGH}$. These slow-migrating components did not seem to be artefacts produced by urea treatment since the major hGH component, reanalysed on urea-containing gels, did not show slow forms, indicating that hGH was not converted to the slower migrating forms by exposure to urea (Lewis et al., 1980b). Both the slow forms had growth-promoting and lactogenic activities, but the faster migrating one had greater lactogenic potency than the major form of $\mathrm{hGH}$.

5) a and $c h G H$ forms. - After removal of all previously described mass and charge variants, purified hGH preparations could be expected to be "pure ». However, when Lewis et al. analysed such a "pure» preparation on isoelectric focusing in polyacrylamide, they were surprised to observe two additional components flanking the major band designated $1 \mathrm{c}$ and $1 \mathrm{a}$ because of their cathodal and anodal migration behaviour (Lewis et al.. 1976). These components could have been allelic modifications in which aminoacid substitution of neutral residues prevents detection by disc electrophoresis but not by isoelectric 
focusing. The immunological and biological activities of these two forms were not studied further. It is noteworthy that the desamido form (see above) showed the same three components (Lewis et al., 1976).

6) Glycosylated GH. - A recent paper by Sinha and Lewis (1986) deals with a putative glycosylated $\mathrm{hGH}$ detected in human pituitary gland. The analysis of hGH-related genes predicts that such a form can exist (Moore et al., 1982). The $\mathrm{hGH}-\mathrm{V}$ gene differs from the normal hGH-N gene at 13 positions of the amino-acid sequence (see below). One of the substitutions involves the replacement of Lys-140 by AsN, giving rise to an AsN-GIN-Ser sequence, an appropriate sequence for $\mathrm{N}$-linked glycosylation. Sinha and Lewis using a lectin binding immunoassay think that they have identified such a glycosylated $\mathrm{GH}$.

At a recent symposium devoted to growth hormone and growth factor research held in Milan, Berghman et al. (1987) told of the discovery in chick of two glycosylated variants, a minor one of $22 \mathrm{~K}$ indistinguishable from the $22 \mathrm{~K}$ holoprotein, and a major form of $25 \mathrm{~K}$. These two forms together accounted for 3 to $5 \%$ of the total GH content of chicken pituitary.

7) Phosphorylated GH. - Liberti et al. (1985) showed that a naturally-occurring ovine $\mathrm{GH}$ was phosphorylated. This supposes the existence of a $\mathrm{GH}$ kinase. To date, other pituitary hormones lack phosphorylated forms. This suggests that the putative kinase is highly specific for $\mathrm{GH}$ or may be contained within somatotrophs and, therefore, that it is not accessible to the other hormones.

The same group also identified phosphorylated $\mathrm{GH}$ in rat anterior pituitary incubated in a $32 \mathrm{P}_{\mathrm{i}}$ containing medium as well as in the medium itself. Gel filtration on Sephadex G-75, SDS-PAGE and autoradiography indicated that phosphorylated $\mathrm{GH}$ was synthesized and secreted by rat pituitary glands in vitro (Liberti and Joshi, 1986).

\section{Others kinds of GH.}

1) Bioinactive GH. - Some years ago, the failure of children to grow was sometimes attributed to functional hGH deficiency resulting from pituitary secretion of a structurally abnormal hGH with substantial immunoreactivity but little or no bioactivity. The bioinactive hGH concept was first introduced by Kowarski et al. (1978), then by several authors after a series of convergent observations on children with growth retardation and delayed bone age. These children showed: normal basal levels of $h \mathrm{GH}$, normal hGH response to provocative tests, subnormal RRA/RIA ratios (about 0.4 ), subnormal $\mathrm{SmC}$ levels (about $0.2 \mathrm{IU} / \mathrm{ml}$ ) and $\mathrm{SmC}$ levels which could be corrected and growth velocity normalized by appropriate GH treatment (data from Kowarski et al., 1978 ; Hayek et al., 1978; Frazer et al., 1980; Rudman et al., 1981). The criteria for a bioinactive $\mathrm{GH}$ diagnosis are listed in table 5 . For more extensive data and comments, the reader will refer to Chawla et al. (1983). 
Diagnostic criteria for bioinactive $h G H$ in short children (from Chawla et al., 1983 (reproduced, with permission, from the Annu. Rev. Med., vol. 34, C 1983, by Annu. Rev. Inc.).

1. Peak $\mathrm{GH}(\mathrm{RIA})$ after provocative tests and during sleep $>12 \mathrm{ng} / \mathrm{ml}$.

2. Current height $<3$ rd percentile.

3. Bone age/chronologic age $<0.8$.

4. Growth velocity below normal for chronologic age by two standard deviations (2 SD) or more.

5. Plasma SmC (average of three estimates) below normal average for chronologic age by 2 SD or more.

6. RRA/RIA ratio for serum $\mathrm{GH}$ below normal average by $2 \mathrm{SD}$ or more.

7. Normalization of $\mathrm{SmC}$ after 10 days' hGH at $0.08 \mathrm{units} / \mathrm{kg} /$ day.

8. Normalization of growth velocity and serum $\mathrm{SmC}$ during 6 months treatment with hGH at 0.08 units $/ \mathrm{kg} /$ day.

9. Growth velocity and $S m C$ decline to subnormal rates within 2 months and within 10 days, respectively, after long-term hGH treatment is stopped.

2) Simian virus human growth hormone-2 (SV-hGH-2).--The gene coding for $22 \mathrm{~K}$ and $20 \mathrm{~K}$ is called $\mathrm{hGH}-\mathrm{N}$ (see above). Another gene coding for a pre- $\mathrm{GH}$ form with 15 aminoacid substitutions ( 2 in the leader peptide and 13 distributed throughout the «mature» protein chain) was reported by Seeburg (1982) and called hGH-V. It is not known if this gene is normally expressed in pituitary, but it was expressed in a monkey kidney cell system by cloning in a simian virus (Pavlakis et al., 1981). This new hGH molecule has an alkaline isoelectric $\mathrm{pH}$ of 8.9, mainly due to the loss of two acidic aminoacids and the benefit of three basic ones, suggesting that the alkaline forms (see above) found in pituitary extracts could be an expression of this newly-recognized gene. If this $\mathrm{hGH}-\mathrm{V}$ gene was expressed in vivo, the synthesized product, SV-hGH-2, could account for the hGH species with high biological and weak immunological activities found in $80 \mathrm{~K}$ (see above) and some $22 \mathrm{~K}$ fractions (see charge variants). Moreover, SV-hGH-2 tends to aggregate. According to findings of the Hennen group in Belgium (Hennen et al., 1985b), the hGH-V gene is actually expressed in vivo, at least in women, at the placental level to give rise to the newly-recognized human placental growth hormone, hPGH.

3) $h G H 17.5 \mathrm{~K}$. - In a recent work, Lecomte et al. (1987), using a human pituitary cDNA library, reported that they have cloned three distinct hGH cDNAs, coding respectively for the well-known $22 \mathrm{~K}$ and $20 \mathrm{~K}$ forms and a yet unknown $17.5 \mathrm{~K}$ variant. The sequence of the concerned cDNA lacks the $120 \mathrm{bp}$ corresponding to the entire third exon and encodes a protein of $17.5 \mathrm{Kd}$, a " truncated" hGH which lacks the 40 aminoacid residues coded by exon 3 and has never been reported in the literature. The biological features of this new putative $\mathrm{hGH}$ variant are still unknown.

4) Placental hGH. - In early 1985, Hennen reported the discovery of a new human growth hormone occurring during the second half of gestation and 
synthesized by the placenta (Hennen et al., 1985a). By means of two monoclonal antibodies, specific either for an epitope, represented essentially by the $\mathrm{N}$ terminal sequence of $22 \mathrm{~K}$ and $20 \mathrm{~K}$, or for another one more internally located and absent in the $20 \mathrm{~K}$, they were able to determine that pituitary secretion disappears after the 25th week of pregnancy. Simultaneously, from week 25 up to parturition, a GH-like material, restricted to maternal circulation and assumed to originate from the placenta, appears in the blood. This human placental GH (hPGH) disappears rapidly at delivery. hPGH most likely originates from the placenta as it is 10-fold more concentrated in this tissue than in serum (Hennen et al., 1985a). It was extracted from that organ and then partially purified using ion-exchange and immunoaffinity chromatographies (Hennen et al., 1985b; Frankenne et al., 1987c). hPGH was demonstrated to be more basic than pituitary $\mathrm{GH}$, whose isoelectric point is around 5.5, and to be composed of two forms of $22 \mathrm{~K}$ and $25 \mathrm{~K} \mathrm{MW}$, respectively (Hennen et al., 1985b). Pure hPGH, obtained through preparative electrophoresis, behaved as a complete agonist to pituitary $\mathrm{GH}$ for binding to $\mathrm{GH}$ hepatic receptors, for which it displayed a 2 -fold higher binding potency (Frankenne et al., 1987b). As its characteristics are very similar to those of the $\mathrm{GH}-\mathrm{V}$ protein and since the placental expression of the $\mathrm{GH}-\mathrm{V}$ gene has been evidenced (Frankenne et al., 1987a), hPGH represents the natural product of the GH-V gene. In such a case, hPGH could be considered as a true isohormone of hGH-22 K. hPGH is unlikely to play any significant direct role in fetal development since it has not been detected in the fetal compartment (Frankenne et al., 1987b). It has been shown recently (Caufriez et al., 1987) that maternal serum IGF-I levels are significantly correlated with hPGH concentrations, but not with $\mathrm{hPL}$ or pituitary $\mathrm{GH}$ concentrations. Therefore, $\mathrm{hPGH}$ is most probably involved in a mechanism by which the placenta progressively replaces the pituitary in controlling the mother's metabolism, favouring the fetus' well-being and development.

The main characteristics of $\mathrm{GH}$ variants have been summarized in table 6 .

\section{GH heterogeneity in other species.}

Growth hormone polymorphism is not restricted to the human species. Multiple forms of $\mathrm{GH}$ were detected in several pituitary extracts from rats, pigs, bovine and sheep. Schleyer et al. (1982) isolated five subfractions of porcine GH with slightly different aminoacid compositions. After $\mathrm{hGH}$, the bovine hormone has been the most extensively studied in this respect. Ruminant growth hormones are single chains of about $20-22,000$ daltons which tend to aggregate, and in neutral solution and at moderate concentrations dimers tend to predominate. This fact led to some incertitude for many years concerning its actual molecular weight (Wallis and Davies, 1976). One heterogeneity comes from the existence of two $\mathrm{N}$-terminal residues, either Ala or Phe (Li and Ash, 1953; Wallis, 1969, 1973). The nature of this $\mathrm{N}$-terminal heterogeneity was elucidated by investigating the $\mathrm{N}$-terminal sequence. Wallis (1969) showed that there were two $\mathrm{N}$-terminal sequences which differed only in the presence or the absence of an extra 


\section{TABLE 6}

Summary of the main biological activities of the main $h G H$ variants. In all columns (except for $\%$ and ratios) the numbers express the relative potency of the variant versus the reference hGH-22 K. $\mathrm{mb} .=$ membranes.

\begin{tabular}{|c|c|c|c|c|c|c|c|c|}
\hline & Variant & $\%$ & RIA & Tibia & $\frac{\text { Tibia }}{\text { RIA }}$ & Crop sac & RRA & $\frac{\mathrm{RRA}}{\mathrm{RIA}}$ \\
\hline $\begin{array}{c}\text { Reference } \\
\text { hGH }\end{array}$ & $22 \mathrm{~K}$ & $70-85$ & 1 & 1 & 1 & 1 & 1 & 1 \\
\hline \multirow{4}{*}{$\begin{array}{c}\text { Mass } \\
\text { variants }\end{array}$} & $45 \mathrm{~K}$ (big) & $15-50 \%$ & pit. $0.1-0.5$ & 0 & 0 & $\leqslant 0.5$ & $\begin{array}{l}\text { human } \\
\text { lymphocytes } \\
0.2-0.4\end{array}$ & \\
\hline & $\begin{array}{l}>45 \mathrm{~K} \\
\text { (big big) }\end{array}$ & $\begin{array}{c}\text { of total } \\
\text { RIA }\end{array}$ & plasma 1 & 0 & & & & \\
\hline & $\begin{array}{r}60-80 \mathrm{~K} \\
24 \mathrm{~K}\end{array}$ & & $\begin{array}{l}0 \\
1\end{array}$ & $\begin{array}{c}x> \\
0\end{array}$ & & $\begin{array}{l}0.5-2 \\
>1\end{array}$ & & \\
\hline & $20 \mathrm{~K}$ & $10-15$ & $0.3-1$ & 1 & & 9 & $\begin{array}{l}\text { rat liver mb. } \\
0.03-0.2 \\
\text { fem. rabbit } \\
\text { mamm. mb. } \\
0.2-0.5\end{array}$ & $\leqslant 1$ \\
\hline \multirow{4}{*}{$\begin{array}{l}\text { Charge } \\
\text { variants }\end{array}$} & $\begin{array}{l}\alpha_{2} \\
\alpha_{3}\end{array}$ & & $\begin{array}{l}1 \\
1\end{array}$ & $\begin{array}{c}1 \\
4-5\end{array}$ & 1 & $\begin{array}{r}5 \\
10\end{array}$ & & \\
\hline & $\begin{array}{l}\text { Fast-GH }(\mathrm{N}- \\
\text { acetylated) }\end{array}$ & 5 & 1 & 1 & & 1 & & \\
\hline & Slow-hGH & & 1 & 1 & 1 & $\geqslant 1$ & & \\
\hline & $\begin{array}{l}\text { Deamidated } \\
\text { forms }\end{array}$ & & & 1 & & & & \\
\hline \multirow[b]{2}{*}{$\begin{array}{c}\text { Other } \\
\text { variants }\end{array}$} & $\begin{array}{l}\text { Bioinactive } \\
\text { hGH }\end{array}$ & & 1 & & & \multicolumn{2}{|r|}{$<0.4$} & $<0.4$ \\
\hline & Sv-hGH-2 & & $0.05-0.10$ & & & & $\begin{array}{l}\text { IM-9 human } \\
\text { lymphocytes } \\
0.5 \\
\text { fem. rabbit } \\
\text { liver mb.1 }\end{array}$ & $\begin{array}{l}>10 \\
>20\end{array}$ \\
\hline
\end{tabular}

$\mathrm{N}$-terminal alanine. The two chains were always obtained in approximately equal amounts (Wallis and Davies, 1976). Pena et al. (1969) showed that the origin of this variation was not allelic but probably arose from the ambiguous processing of a $\mathrm{GH}$ precursor. This $\mathrm{N}$-terminal heterogeneity was also observed in oGH (Pena et al., 1970). A second variation in the bGH (never the oGH) molecule was found at position 127, where Val or Leu are alternatively found, at a ratio of about 1/2 (Fellows and Rogol, 1969 ; Fernandez et al., 1971). Seavey et al. (1971), studying individual beef pituitaries, showed that, in an individual gland, residue 127 could be all Leu or all Val, or both. Thus, they demonstrated that variation at this position was due to allelic polymorphism in the cows from which the hormone was derived. However, a recombinant-derived bGH produced by $E$. coli was reported to be more homogeneous than that derived from pituitary sources 
and was greater than $95 \%$ of a single polypeptide entity (Brems et al., 1985). By chromatography on DEAE-Sephacel, Hart et al. (1984) resolved pituitaryextracted bGH into four protein peaks (A, B, C, D). By immunological, physiological and metabolic criteria, they were shown to differ relatively from one another. For instance, all were equally lipolytic, but fraction $D$ had a greater growth-promoting capacity than the others and was only weakly immunoreactive.

In non-mammals, the Phe and Leu were found at the N-terminal of duck (avian) and turtle (reptilian) GH preparations (Papkoff and Hayashida, 1972), but were not confirmed in ulterior publications; they were perhaps due to some degradation during the purification steps. Besides the glycosylated $\mathrm{GH}$ already mentioned in avian preparations (Berghman et al., 1987), Goddard and Houston (1987) reported the existence of at least 10 charge variants of chicken $\mathrm{GH}$ in a range of $14 \mathrm{~K}$ to $66 \mathrm{~K}$ forms, the predominant one being $24 \mathrm{~K}$. Another microheterogeneity was observed at the $\mathrm{N}$-terminal of sea turtle with $\mathrm{NH}_{2}-(\mathrm{Ala}$ or Phe or Leu)... (Farmer et al., 1976). The teleost fish, Tilapia, was reported to present $\mathrm{N}$-terminal variants. Aminoacids Ile, Leu and Val were found at the $\mathrm{N}$-terminus, but Pro was always the only second aminoacid (i.e. $\mathrm{NH}_{2}$ - (Ile or Leu or Val)-Pro... (Papkoff et al., 1980). Recently, two forms of growth hormone were purified from the medium of eel pituitaries in organ culture. The two variants identified, eGH I and eGH II, were highly similar to each other with a molecular weight of 23,000 daltons. Both $\mathrm{eGH} \mathrm{I}$ and $\mathrm{eGH} I \mathrm{I}$ are likely to be secreted from a single pituitary. The $\mathrm{N}$-terminal aminoacid is $\mathrm{Val}$ for $\mathrm{eGH} \mathrm{I}$ and Ileu for eGH II, and the isoelectric points are 6.3 and 6.7 , respectively. Both were equipotent to ovine $\mathrm{GH}$ to promote growth in juvenile rainbow trout (Kishida et al., 1987).

\section{Conclusions.}

Considerable progress has been made in recent years concerning what is known about the structure of growth hormone and its many variants, which are still increasing in number. The biological role of these newly-recognized hormones and their full physiological significance has not been elucidated yet. Several hypotheses have been put forward to explain the variety of $\mathrm{GH}$ action : a) the $\mathrm{GH}$ molecule may be subdivided into two parts, one anabolic and the other catabolic (Levine and Luft, 1964) ; b) the $\mathrm{GH}$ molecule may be a prohormone which delivers more specific active fragments after enzymatic attack or hydrolysis by the plasma cell membrane (Bornstein et al., 1973); c) the attractive hypothesis of Mills $e t$ al. (1980) suggests that a variety of receptors at the target level could react with different regions of the $\mathrm{GH}$ molecule, each inducing a specific biological effect.

Whatever the mechanisms involved in hormone action, it is evident that alterations in charge, mass and in circulating forms, freely moving or bound to proteins, considerably modify the sites exposed to proteolytic attack or to cell receptors, hence directing the biological effect in such and such a way. An overall hypothesis is that proteolytic processing of a variety of forms of $\mathrm{GH}$, each acting 
as a specific substrate, could produce numerous fragments with affinities for specific receptors (Lewis, 1984). In the experimental or clinical field, one must keep in mind that, whatever the assay used, $\mathrm{GH}$ concentrations never deal with a sole molecular species (except for monoclonal antibodies), but integrate all forms. Further structure-function relationship studies are needed to clarify the relative biological importance of each of them.

Reçu en juillet 1987. Accepté en mars 1988.

Acknowledgements. - We wish to thank Acta Endocrinologica, Annual Review Inc. and the authors mentioned for granting permission to reproduce their figures and tables. Secretarial help was provided by Mrs Marie-Claude Cavailhès.

\section{Addenda}

Since this manuscript was submitted, some data in the field of GH polymorphism have appeared, which must be added to this rewiew.

a) concerning $h G H$ dimers. Becker et al. (1987) demonstrate that hGH dimers extracted from various commercial batches of pituitary hGH, biosynthetic hGH and biosynthetic methionyl-hGH are essentially in a noncovalent dimer form. The authors underline that the commonly used SDS-PAGE is not suitable for detecting noncovalent dimers (because of dissociation into monomers), and that size-exclusion HPLC is the method of choice to achieve a valuable separation. Such dimers are much less bioactive than monomers, but exhibit similar reactivities in polyclonal RIA analysis. However the dimers $\mathrm{ED}_{50}$ values are significantly lower, and with an appropriate monoclonal antibody immunoreactivity falls to $22 \%$ compared to monomeric hGH.

Becker G. W., Bowsher R. R., Mackellar W. C., Poor M. L., TackitT P. M., Riggin R. M., 1987. Chemical, physical and biological characterisation of a dimeric form of biosynthetic human growth hormone. Biotechnol. appl. Biochem., 9, 478-487.

b) concerning non immunoreactive but bioactive $G H$. Kowarski et al. (1978) were the first to report the bioinactive $\mathrm{GH}$ syndrome (see text). The same group describes now the opposite clinical picture : normal growth in 4 boys with no RIA-GH. Normal plasma GH concentrations are evidenced by IM- 9 cell RRA. The RRA/RIA ratio in a range of 4 to 14 largely exceeded that of controls. The authors conclude that these patients secrete a molecule with normal receptor binding and bioactivity which is " invisible " to the standard GH-RIA. This variant GH is possibly expressed from the human GH-V gene or a mutant allele. This data is consistent with that of the $80 \mathrm{~K}$ variant of Ellis et al. (see text) who found a tibia/RIA ratio very elevated for this variant.

Bistrizer T., Chalew S. A., Lovchik J. C., Kowarski A. A., 1988. Growth without growth hormone the « invisible" GH syndrome. Lancet, I, 321-323.

c) concerning $\mathrm{GH}$ binding protein. A fraction of growth hormone receptor from rabbit liver and the growth hormone binding protein from rabbit serum have the same amino-acid sequence, indicating the binding protein corresponds to the extracellular hormone-binding domain of the liver receptor (Leung et al. 1987). Clones of both the rabbit and human GH receptors were isolated. The whole putative receptor would have a MW of $130 \mathrm{~K}$ and comprise 620 residues. The hydrophobic region from residues 247-270 probably represents a transmembrane domain, leaving 246 residues at the amino-terminal end as an extra-cellular domain, which presumably binds $\mathrm{GH}$, and 350 residues on the cytoplamic side. The MW is actually heavier than that predicted from the sequence and can be largely accounted for by glycosylations on eight $\mathrm{As} N$ residues (Wallis, 1987). When expressed in mammalian cells, the cloned rabbit protein can bind both hGH and bGH, whereas the cloned human protein can bind only hGH but not bGH, a species specificity very similar to that seen in the biological actions of growth promotion. Moreover the complete primary structures derived from complementary DNA clones encoding the putative human and rabbit growth hormone receptor are not similar to other known proteins, demonstrating a new class of transmembrane receptors. 
Leung D. W., Spencer S. A., Cachianes G., Hammonds R. G., Collins C., Henzel W. J., Barnard R., Waters M. J., WOOD W. I., 1987. Growth hormone receptor and serum binding protein : purification, cloning and expression. Nature, 330, 537-543

WalLIS M., 1987. Growth-hormone receptor cloned. Nature, 330, 521-522.

\section{Résumé. Les hormones de croissance. 1. Polymorphisme.}

Lorsqu'on parle de l'hormone de croissance hypophysaire, on n'évoque pas seulement une espèce moléculaire, mais tout un ensemble de molécules apparentées, dont les particularismes individuels constituent le polymorphisme de la $\mathrm{GH}$ ( $\mathrm{GH}=$ growth hormone). Cet article traite essentiellement des différentes formes, appelées variants, de la $\mathrm{GH}$ humaine, mais évoque aussi ce polymorphisme chez les autres espèces.

La forme prédominante de toutes ces $\mathrm{GH}$ est le variant $22 \mathrm{~K}$ ( $\mathrm{PM}=22000$ daltons), auquel les autres variants sont comparés, tant au point de vue de la structure chimique que des actions biologiques. On les classe selon deux grands groupes : les variants de masse (dont la masse moléculaire se trouve modifiée par rapport au $22 \mathrm{~K}$ ), qui se divisent en formes agrégées ou non agrégées, et les variants de charge (mobilité électrophorétique différente). En dehors de cette classification se trouvent des entités encore mal connues, comme la GH bioinactive, normalement détectée par RIA mais sans activité biologique, ou au contraire fortement bioactive mais non immunoréactive, ce qui pose de sérieux problèmes pour son étude. S'y ajoute la forme SV-hGH-2, qui serait codée par un gène différent de celui responsable de la synthèse des autres variants. Dans ce cas on aurait à faire non plus à un variant, mais à une isohormone. Cependant l'expression de ce gène n'a encore jamais été mise en évidence dans l'hypophyse. Mais, selon des données récentes, il pourrait être exprimé au niveau placentaire, et être impliqué dans la synthèse de l'hPGH (human placental growth hormone), hormone de croissance nouvellement découverte, qui chez la femme prend le relai de la GH hypophysaire à partir de la $25^{\mathrm{e}}$ semaine de grossesse.

Après libération par l'hypophyse dans la circulation, les molécules de $\mathrm{GH}$ sont partiellement prises en charge et transportées par des protéines de liaison. Le rôle physiologique de ce phénomène pourrait être la constitution d'un réservoir et d'un système d'économie de la $\mathrm{GH}$, la clairance métabolique du complexe $\mathrm{GH}$-protéine de liaison étant plus faible que celle de la GH libre, ce qui augmente la demi-vie biologique de l'hormone.

\section{References}

ASTON R., HOLDER A. T., PREECE M. A., IVANYI J., 1986. Potentiation of the somatogenic and lactogenic activity of human growth hormone with monoclonal antibodies. J. Endocr., 110. $381-388$.

BAUMANN G., 1976. Metabolic clearance rates of isohormones of human growth hormone in man. J. clin. Endocrinol. Metab., 49, 495-499.

BAUMANN G., 1987. Circulating growth hormone binding proteins. J. Endocr. Investig., 10, $2^{\text {nd }}$ suppl. $n^{\circ} 4$. Abstr. $n^{\circ} 5$.

BAUMANN G., ABRAMSON E. C., 1983. Urinary growth hormone in man : evidence for multiple molecular forms. J. clin. Endocrinol. Metab., 56, 305-311.

BAUMANN G., Mac CART J. G., 1982. Growth hormone production of human pituitary glands in organ culture: evidence for predominant secretion of the single-chain 22,000 molecular weight form (isohormone B). J. clin. Endocrinol. Metab., 55, 611-617.

BAUMANN G., Mac CART J. G., AMBURN K., 1983. The molecular nature of circulating growth hormone in normal and acromegalic man : evidence for a principal and minor monomeric forms. J. clin. Endocrinol. Metab., 56, 946-952.

BAUMANN G., NISSLEY S.P., 1979. Somatomedin generation in response to activated and non-activated isohormones of human growth hormone. J. clin. Endocrinol. Metab., 48 , 246-250. 
BAUMANN G., STOLAR M. W., 1986. Molecular forms of human growth hormone secreted in vivo: non specificity of secretory stimulus. J. clin. Endocrinol. Metab., 62, 789-790.

BAUMANN G., STOLAR M.W., AMBURN K., 1985a. Molecular forms of circulating growth hormone during spontaneous secretory episodes and in the basal state. J. clin. Endocrinol. Metab., 60, 1216-1220.

BAUMANN G., STOLAR M. W., BUCHANAN T. A., 1985b. Slow metabolic clearance rate of the 20,000-dalton variant of human growth hormone: implications for biological activity. Endocrinology, 117, 1309-1313.

BAUMANN G., STOLAR M. W., AMBURN K., BARSANO C. P., De VRIES B. C., 1986a. A specific growth hormone-binding protein in human plasma: initial characterization. J. clin. Endocrinol. Metab., 62, 134-141.

BAUMANN G., STOLAR M. W., BUCHANAN T. A., 1986b. The metabolic clearance, distribution and degradation of dimeric and monomeric growth hormone $(\mathrm{GH})$ : implications for the pattern of circulating GH forms. Endocrinology, 119, 1497-1501.

BEITINS I. Z., RATTAZZI M. C., Mac GILLIVRAY M. H., 1977. Conversion of radiolabelled human growth hormone into higher molecular weight moieties in human plasma in vivo and in vitro. Endocrinologv, 101, 350-359.

BENVENISTE R., STACHURA M. E., SCABO M., FROHMAN L. A., 1975. Big growth hormone $(\mathrm{GH})$ : conversion to small GH without peptide cleavage. J. clin. Endocrinol. Metab., 41. $422-425$.

BERGHMAN L. R., LENS P., KÜHN E. R., VANDESANDE F., 1987. Discovery and isolation of the glycosylated chicken growth hormone $(\mathrm{GH})$ variant. J. Endocr. Investig., 10, $2^{\text {nd }}$ suppl. $n^{\circ} 4$. Abstr. $n^{\circ} 7$.

BORNSTEIN J., ARMSTRONG J., Mc D., TAFT H.P., NG F. M., GOULD M. K., 1973 . The mechanism of the diabetogenic effects of pituitary growth hormone. Postgrad. Med. J. (Suppl.), 49, 219-242.

BREMS D. N., PLAISTED S. M., HAVEL H. A., KAUFFMAN E. W., STODOLA J. D., EATON L. C., WHITE R. D., 1985 . Equilibrium denaturation of pituitary-and recombinant-derived bovine growth hormone. Biochemistry, 24, 7662-7668.

CAUFRIEZ A., FRANKENNE F., HENNEN G., CANTRAINE F., GOLSTEIN J., COPINSCHI G., 1987. Close relationship between maternal somatomedin-C and placental hGH levels during normal human pregnancy. In Abstr. 69th Ann. Meet. Endocr. Soc. (Indianapolis, June 10-12), Abstr. 672

CHAWLA R. K., PARKS J. S., RUDMAN D., 1983. Structural variants of human growth hormone : biochemical, genetic, and clinical aspects. Ann. Rev. Med., 34, 519-547.

CHÊNE N., MARTAL J., De La LLOSA P., CHARRIER J., 1988. Growth hormones. 2. Structure-function relationships. Reprod. Nutr. Dévelop., 28, (in press).

CHRAMBACH A., YADLEY R. A., BEN-DAVID M., RODBARD D., 1973. Isohormones of human growth hormone. I. Characterization by electrophoresis and isoelectric focusing in polyacrylamide gel. Endocrinology, 93, 848-857.

CLOSSET J., SMAL J., GOMEZ F., HENNEN G., 1983. Purification of the 22000- and 20000- mol. wt. forms of human somatotropin and characterization of their binding to liver and mammary binding sites. Biochem. J., 214, 855-892.

DE NOTO F. M., MOORE D. D., GOODMAN H. M., 1981. Human growth hormone DNA sequence and RNA structure: possible alternate splicing. Nucleic Acids Res., 9, 3719-3730.

ELLIS S., GRINDELAND R. E., REILLY T. J., YANG S. H., 1976. Studies on the nature of plasma growth hormone. A. PECILE, E. E. MULLER, In Growth hormone and related peptides New-York, Elsevier, p. 64-74.

ELLIS S., VODIAN M. A., GRINDELAND R. E., 1978. Studies on bioassayable growth hormone-like activity of plasma. Recent. Progr. Horm. Res., 34, 213-238.

FARMER S. W., PAPKOFF H., HAYASHIDA T., 1976. Purification and properties of reptilian and amphibian growth hormones. Endocrinology, 99, 692-700.

FELLOWS R. E., ROGOL A. D., 1969. Structural studies on bovine growth hormone. I. Isolation and characterization of cyanogen bromide fragments. J. biol. Chem., 244, 1567-1575. 
FERNANDEZ H. N., DAURANT S. T., PENA C., DELLACHA J. M., SANTOME J. A., PALADINI A. C., 1971. Localization of a microheterogeneity in the aminoacid sequence of bovine growth hormone. FEBS Lett., 18, 53-54.

FLORINI J. R., TONELLI G., BREUER C. B., COPPOLA J., RINGLER I., BELL P. H., 1966 . Characterization and biological effects of purified placental protein (human). Endocrinology, 79 , $692-708$.

FRANKENNE F., RENTIER-DELRUE F., SCIPPO M. L., MARTIAL J., HENNEN G., 1987a. Expression of the growth hormone variant gene in human placenta. J. clin. Endocrinol. Metab., 64 , 635-637.

FRANKENNE F., GOMEZ F., PIRENS G., SCIPPO M. L., HENNEN G., 1987b. Human placental growth hormone : secretion profile, distribution and partial characterization. (Submitted for publication.)

FRANKENNE F., PIRENS G., GOMEZ F., HENNEN G., 1987c. Découverte d'un variant placentaire de l'hormone de croissance humaine : biochimie, physiologie et implication dans la sécrétion des formes hypophysaires. Reprod. Nutr. Dévelop., 27, 523-524.

FRAZER T. E., GAVIN J. R., DAUGHADAY W. H., HILLMAN R. E., WELDON V. V., 1980. Growth hormone dependent growth failure. Pediatr. Res., 14, 478

FRIESEN H., 1965. Purification of placental factor with immunological and chemical similarity to human growth hormone. Endocrinology, 76, 369-381.

FRIGERI L. G., PETERSON S. M., LEWIS U. J., 1979. The 20000 dalton structural variant of human growth hormone : lack of some early insulin-like effects. Biochem. Biophys. Res. Commun. 91, 778-782

FROHMAN L. A., BUREK L., STACHURA M. E., 1972. Characterization of growth hormone of different molecular weights in rat, dog, and human pituitaries. Endocrinology, 91, 262-269.

GAYE P., GAUTRON J.P., MERCIER J.C., HAZE G., 1977. Amino-terminal sequences of the precursor of ovine caseins. Biochem. Biophys. Res. Comm., 79, 903-911

GODDARD C., HOUSTON B., 1987. Monoclonal antibody to chicken growth hormone recognises different charge forms in the pituitary gland. J. Endocr. Investig., 10, $2^{\text {nd }}$ suppl. $n^{\circ} 4$, Abst. $\mathrm{n}^{\circ} 13$.

GOODMAN H. M., DE NOTO F., FIDDES J. C., HALLEWELL R. A., PAGE G. S., SMITH S., TISCHER E., 1980. Structure and evolution of growth hormone related genes. In Mobilization and reassembly of genetic information, Miami Winter Symp., ed. W. A. SCOTT, R. WERNER, D. R. JOSEPH, J. SCHULTZ, pp. 15-179. New York Acad.

GUYDA H. J., 1975. Heterogeneity of human growth hormone and prolactin secreted in vitro. immunoassay and radioreceptor assay correlations. J. clin. Endocrinol. Metab., 41, 953-967.

HART I. C., BLAKE L. A., CHADWICK P.M. E., PAYNE G. A., SIMMOND A. D., 1984. The heterogeneity of bovine growth hormone. Biochem. J., 218, 573-581.

HAYEK A., PEAKE G. T., GREENBERG R. E., 1978. A new syndrome of short stature due to biologically inactive but immunoactive growth hormone. Pediatr. Res., 12, 413.

HENDRICKS C. M., EASTMAN R. C., TAKEDA S., ASAKAWA K., GORDEN P., 1985. Plasma clearance of intraveneously administered pituitary human growth hormone: gel filtration studies of heterogeneous components. J. clin. Endocrinol. Metab., 60, 864-867

HENNEN G., FRANKENNE F., CLOSSET J., GOMEZ F., PIRENS G., EL KHAYAT N., 1985a. A human placental $\mathrm{GH}$ : increasing levels during second half of pregnancy with pituitary $\mathrm{GH}$ suppression as revealed by monoclonal antibody radioimmunoassays. Int $J$. Fertil, 30 , $27-33$.

HENNEN G., FRANKENNE F., CLOSSET J., GOMEZ F., PIRENS G., SMAL J., BECKERS A., EL KHAYAT N., LAMBOTTE R., 1985b. Monoclonal antibody to growth hormone: the discovery of a new variant, human placental growth hormone. Int. Symp. on Monoclonal antibodies : basic principles, experimental and clinical applications in endocrinology. ARES Serono Symposia: G. FORTI, M. SERIO and M. B. LIPSETT Eds., Raven Press, New-York, 30, $29-40$.

HERINGTON A. C., YMER S., STEVENSON J., 1986. Identification and characterization of specific binding proteins for growth hormone in normal human sera. J. c/in. Invest., 77, 1817-1823. 
HUBBARD J.R., LIBERTI J.P., 1980. Somatomedin-like bioactivities of a growth hormone fragment on embryonic chick cartilage and cultured human fibroblasts. Biochim. Biophys. Acta, 627, 207-214.

JOSIMOVITCH J. B., Mac LAREN J. A., 1962. Presence in the human placenta and term serum of a highly lactogenic substance immunologically related to pituitary growth hormone. Endrocrinology, 71, 209-220.

KAPLAN S. L., GRUMBACH M. M., 1965. Immunoassay for human chorionic " growth hormoneprolactin " in serum and urine. Science, 147, 751-753.

KAWAUCHI H., YASUDA A., 1987. Evolutionary aspects of growth hormones from mammalian species. J. Endocr. Investig., 10, $2^{\text {nd }}$ suppl. $n^{\circ} 4$, Abst. $n^{\circ} 4$.

KISHIDA M., HIRANO T., KUBOTA J., HASEGAWA S., KAWAUCHI H., YAMAGUCHI K., SHIRAHATA K., 1987. Isolation of two forms of growth hormone secreted from eel pituitaries in vitro. Gen. comp. Endocrinol., 65, 478-488.

KOHLER P. O., BRIDSON W. E., CHRAMBACH A., 1971. Human growth hormone produced in tissue culture : characterization by polyacrylamide gel electrophoresis. J. clin. Endocrinol. Metab., 32, 70-76.

KOSTYO J. L., CAMERON C. M., OLSON K. C., JONES A. J.S., PAI R. C., 1985 . Biosynthetic 20-kilodalton methionyl-human growth hormone has diabetogenic and insulin-like activities. Proc. nat. Acad. Sci. USA, 82, 4250-4253.

KOWARSKI A. A., SCHNEIDER J., BEN GALIM E., WELDON V.V., DAUGHADAY W. H., 1978. Growth failure with normal serum RIA-GH and low somatomedin activity: somatomedin restoration and growth acceleration after exogenous GH. J. clin. Endocrinol. Metab., 47, $461-464$.

LECOMTE C. M., RENARD A., MARTIAL J.A., 1987. A new natural hGH variant-17.5 Kdproduced by alternative splicing. An additional consensus sequence which might play a role in branchpoint selection. Nucl. Acids Res., 15, $6331-6348$.

LEVINE R., LUFT R., 1964. The relation between the growth and diabetogenic effects of the so-called growth hormone of the anterior pituitary. Diabetes, 13, 651-655.

LEWIS U. J., 1984. Variants of growth hormone and prolactin and their postranslational modifications. Ann. Rev. Physiol., 46, 33-42.

LEWIS U. J., BONEWALD L. F., LEWIS L. J., 1980a. The 20,000 dalton variant of human growth hormone: location of the aminoacid deletions. Biochem. Biophys. Res. Commun., 92. $511-516$

LEWIS U. J., CHEEVER E. V., 1965. Evidence for two types of conversion reactions for prolactin and growth hormone. J. biol. Chem., 240, 247-252.

LEWIS U. J., DUNN J. T., BONEWALD L. F., SEAVEY B. K., VAN DER LAAN W. P., 1978. A naturally occuring structural variant of human growth hormone. J. biol. Chem., 253 , 2679-2687.

LEWIS U. J., PETERSON S. M., BONEWALD L. F., SEAVEY B. K., VAN DER LAAN W. P., 1977. An interchain disulfide dimer of human growth hormone. J. biol. Chem., 252, 3697-3702.

LEWIS U. J., SINGH R. N. P., BONEWALD L. F., LEWIS L. J., VAN DER LAAN W. P., 1979. Human growth hormone : additional members of the complex. Endocrinology, 104, 1256-1265.

LEWIS U. J., SINGH R. N. P., BONEWALD L. F., SEAVEY B. K., 1981 a. Altered proteolytic cleavage of human growth hormone as a result of deamidation. J. biol. Chem., 256, 11645-11650.

LEWIS U. J., SINGH R. N. J., LINDSEY T. T., SEAVEY B. K., LAMBERT T. H., 1974 . Enzymically modified growth hormone and the diabetogenic activity of human growth hormone. In S. RAITI, Advances in human growth hormone research. DHEW Publication $\mathrm{n}^{\circ}$ 74-612, pp. 349-363.

LEWIS U. J., SINGH R. N. P., PETERSON S. M., VAN DER LAAN W. P., 1976. Human growth hormone: a family of proteins. In A. PECILE, E. E. MULLER, Growth hormone and related peptides, Elsevier, N.Y., pp. 64-74.

LEWIS U. J., SINGH R. N. P., TUTWILER G. F., 1981 b. Hyperglycemic activity of the 20,000 dalton variant of human growth hormone. Endocr. Res. Comm., 8, 155-164.

LEWIS U. J., SINGH R. N. P., TUTWILER G. F., SIGEL M. B., VAN DER LAAN E. F., VAN DER LAAN W. P., 1980b. Human growth hormone: A complex of proteins. Rec. Progr. Horm. Res., 36, 477-504. 
LI C. H., 1972. Recent knowledge of the chemistry of lactogenic hormones. In WOLSTENHOLM G. E., KNIGHT J. Lactogenic hormones, Ciba Found. Symp. Churchill Livingstone, London, p. 7.

LI C. H., ASH L., 1953. The nitrogen terminal end-groups of hypophyseal growth hormone. J. biol. Chem., 203, 419-424.

LIBERTI J. P., ANTONI B. A., CHLEBOWSKI J. F., 1985. Naturally occuring pituitary growth hormone is phosphorylated. Biochem. Biophys. Res. Comm., 128, 713-720.

LIBERTI J. P., JOSHI G. S., 1986. Synthesis and secretion of phosphorylated growth hormone by rat pituitary glands in vitro. Biochem. Biophys. Res. Comm., 137, 806-812.

LIBERTI J. P., MILLER M. S., 1978. Stimulation of human fibroblast protein, ribonucleic acid, and deoxyribonucleic synthesis by bovine growth hormone fragments. Endocrinology, 103. 29-34.

LINGAPPA V. R., BLOBEL G., 1980. Early events in the biosynthesis of secretory and membrane proteins : the signal hypothesis. Recent Prog. Horm. Res., 36, 451-475.

MACIAG T., FORAND R., ISLEY S., CERUNDOLO J., GREENLEE R., KELLEY P. R., CANALIS E., 1980. The generation of sulfation factor activity by proteolytic modification of growth hormone. J. biol. Chem., 255, 6064-6070.

MARKOFF E., LEE D. W., CULLER F. L., JONES K. L., LEWIS U. J., 1986 . Release of the 22,000and the 20,000-dalton variants of growth hormone in vivo and in vitro by human pituitary cells. J. clin. Endocrinol. Metab., 62, 664-669.

MARTAL J,, 1978. Placental growth hormone in sheep : purification, properties and variations. Ann. Biol. anim. Bioch. Biophys., 18, 45-51.

MARTAL J., 1980. L'hormone lactogène placentaire ovine. Thèse d'Etat. Univ. Paris-Sud, 499 pp.

MARTAL J., DJIANE J., 1975. Purification of a lactogenic hormone in sheep placenta. Bioch. Biophys. Res. Comm., 65, 770-778.

MARTAL J., DJIANE J., 1977. Mammotrophic and growth promoting activities of a placental hormone in sheep. J. Steroid Bioch., 8, 415-417.

MILLER W. L., EBERHARDT N. L., 1983. Structure and evolution of the growth hormone gene family. Endocr. Rev., 4, 97-130.

MILLS J. B., KOSTYO J. L., REAGAN C. R., WAGNER S. A., MOSELEY M. H., WILHELMI A. E., 1980. Fragments of human growth hormone produced by digestion with thrombin: chemistry and biological properties. Endocrinology, 107, $391-398$.

MOORE D. D., WALKER M. D., DIAMOND D. J., CONKLING M. A., GOODMAN H. M., 1982. Structure, expression and evolution of growth hormone genes. Rec. Prog. Horm. Res., 38, 197-225.

MURTHY G. S., SCHELLENBERG C., FRIESEN H. G., 1982. Purification and characterization of bovine placental lactogen. Endocrinology, 111, 2117-2124.

NICOLL C. S., 1982. Prolactin and growth hormone : specialists on one hand and mutual mimics on the other. Perspect. Biol. Med., 25, 369-381.

NIXON D. A., JORDAN R. M., 1986. Conversion of CSF monomeric growth hormone to large growth hormone with exposure to serum. Acta endocrinol., 111, 289-295.

PAPKOFF H., FARMER S. W., HAYASHIDA T., 1980. Non-mammalian growth hormones : naturally occuring analogs. In A. PECILE, E. E. MULLER, Growth hormone and other biologically active peptides, Excerpta Medica, Amsterdam, pp. 45-51.

PAPKOFF H., HAYASHIDA T., 1972. Pituitary growth hormone from the turtle and duck purification and immunochemical studies. Proc. Soc. exp. Biol. Med., 140, 251-255.

PAVLAKIS G. N., HIZUKA N., GORDEN P., SEEBURG P. H., HAMER D. H., 1981. Expression of two human growth hormone genes in monkey cells by cloning in simian virus 40. Proc. nat. Acad. Sci. USA., 78, 7398-7402.

PENA C., PALADINI A. C., DELLACHA J. M., SANTOME J. A., 1969. Evidence for non allelic origin of the two chains in ox growth hormone. Biochim. Biophys. Acta, 194, 320-321.

PENA C., PALADINI A. C., DELLACHA J. M., SANTOME J. A., 1970. Structural studies on ovine growth hormone. Cyanogen bromide fragments: $\mathrm{N}$ - and $\mathrm{C}$-terminal sequences. Eur. J. Biochem., 17, 27-31. 
RUDMAN D., KUTNER M. H., BLACKSTON R. D., CUSHMAN R. A., BAIN R. P., PATTERSON J. H., 1981. Children with normal-variant short stature : treatment with human growth hormone for six months. N. Engl. J. Med., 305, 123-131

SCHLEYER M., TRAH T., SCHLEYER I., 1982. Heterogeneity of porcine somatotropin. Hoppe Seyler's Z. Physiol. Chem. 363, 179-185

SEAVEY B. K., SINGH R. N. P., LEWIS U. J., GESHWIND I. I., 1971. Bovine growth hormone: evidence for two allelic forms. Biochem. Biophys. Res. Commun., 43, 189

SEEBURG P. H., 1982. The human growth hormone gene family: nucleotide sequences show recent divergence and predict a new polypeptide hormone. DNA, 1, 239-249

SHOWE B., FRIESEN H. G., 1971. Purification and characterization of monkey placental lactogen. Endocrinology, 89, 631-641.

SIGEL M. B., THORPE N. A., KOBRIN M. S., LEWIS U. J., VAN DER LAAN W. P., 1981. Binding characteristics of a biologically active variant of human growth hormone $(20 \mathrm{~K})$ to growth hormone and lactogen receptors. Endocrinology, 108, 1600-1604.

SIGEL M. B., VAN DER LAAN W. P., KOBRIN M. S., VAN DER LAAN E. F., THORPE N. A., 1982. The biological half-life of human growth hormone and a biologically active 20,000-dalton variant in mouse blood. Endocr. Res. Commun., 9, 67-77.

SIGEL M. B., VAN DER LAAN W. P., VAN DER LAAN E. F., LEWIS U. J., 1980. Measurement of multiple forms of $\mathrm{hGH}$ : cross-reactivities in conventional and two-chain radioimmunoassays. Endocrinology, 106, 92-97

SILVERLIGHT J. J., PRYSOR-JONES R. A., JENKINS J. S., 1985. Growth hormone in normal female rat plasma appears on gel filtration as a large molecular weight form. Life Sciences, 36, 1927-1932.

SINGH R. N. P., SEAVEY B. K., LEWIS U. J., 1974a. Heterogeneity of human growth hormone. Endocr. Res. Commun., 1, 449-464.

SINGH R. N. P., SEAVEY B. K., RICE V. P., LINDSEY T. T., LEWIS U. J., 1974b. Modified forms of human growth hormone with increased biological activities. Endocrino/ogv, 94, 883-891.

SINHA Y. N., 1980. Molecular size variants of prolactin and growth hormone in mouse serum : strain differences and alterations of concentrations by physiological and pharmacological stimuli. Endocrinology, 107, 1959-1969.

SINHA Y. N., LEWIS U. J., 1986. A lectin-binding immunoassay indicates a possible glycosylated growth hormone in the human pituitary gland. Biochem. Biophys. Res. Comm., 140. $491-497$.

SKYLER J. S., ROGOL A. D., LOVENBERG W., KNAZEK R. A., 1977. Characterization of growth hormone and prolactin produced by human pituitary in culture. Endocrinology, 100, 283-291.

SMAL J., CLOSSET J., HENNEN G., DE MEYTS P., 1986. The receptor binding properties of the $20 \mathrm{~K}$ variant of human growth hormone explain its discrepant insulin-like and growth promoting activities. Biochem. Biophys. Res. Commun., 134, 159-165.

SMAL J., CLOSSET J.,. HENNEN G., DE MEYTS P., 1987. Hormone de croissance $22 \mathrm{~K}$ et $20 \mathrm{~K}$ : corrélation entre liaison au récepteur et effet biologique direct sur adipocyte de rat. Reprod. Nutr. Dévelop., 27. $521-522$.

SOMAN V., GOODMAN A. D., 1977. Studies of the composition and radioreceptor activity of "big " and « little » human growth hormone. J. clin. Endocrinol. Metab., 44, 569-581.

SPENCER E. M., LEWIS L. J., LEWIS U. J., 1981. Somatomedin generating activity of the 20 000-dalton variant of human growth hormone. Endocrinologv, 109, 1301-1302.

STOLAR M. W., AMBURN K., BAUMANNN G., 1984. Plasma "big» and «big-big»growth hormone $(\mathrm{GH})$ in man : an oligomeric series composed of structurally diverse $\mathrm{GH}$ monomers. J. clin. Endocrinol. Metab., 59, 212-218.

STOLAR M. V., BAUMANN G., 1986. Big growth hormone forms in human plasma : immunochemical evidence for their pituitary origin. Metabolism, 35, 75-77.

SUSSMAN P. M., TUCHINSKY R. J., BANCROFT F. C., 1976. Pre-growth hormone : product of the translation in vitro of messenger RNA coding growth hormone. Proc. nat. Acad. Sci. USA, 73, 29-33.

TINSLEY F. C., GRINNAN E. L., BAKER S. H., POWELL.J. G., BEMIS K. G., SHAAR C. J., 1986. The 20000 dalton structural variant of recombinant DNA-derived methionyl human growth 
hormone has early insulin-like effects in hypophysectomized rats. Biochem. Biophys. Res. Commun., 138, 342-348.

WALLIS M., 1969. The $\mathrm{N}$-terminus of ox growth hormone. FEBS Lett., 3, 118.

WALLIS M., 1973. The $\mathrm{pK}_{\mathrm{a}}$ values of the $\alpha$-amino groups of peptides derived from the $\mathrm{N}$-terminus of bovine growth hormone. Biochem. Biophys. Acta., 310, 388-397.

WALLIS M., 1978. The chemistry of pituitary growth hormone, prolactin and related hormones, and its relationship to biological activity. In WEINSTEIN B., Chemistry and biochemistry of amino acids, peptides and proteins : A survey of recent developments. Marcel Dekker, New York, vol. 5, 213-320.

WALLIS M., 1980. Growth hormone : deletion in the protein and introns in the gene. Nature, 284, 512-513.

WALLIS M., ASTON R., 1987. Monoclonal antibodies to growth hormone potentiate the actions of the hormone on somatomedin production and growth in the hypophysectomized rat. $J$. Endocr. Investig., 10, supply $n^{\circ} 4$. Abstr. $n^{\circ} 10$.

WALLIS M., DAVIES R. V., 1976. Studies on the chemistry of bovine and rat growth hormones. In A. PECILE, E. E. MULLER, Growth hormone and re/ated peptides. Excerpta Medica, Amsterdam, p. 1-13.

WOHNLICH L., MOORE W. V., 1982. Binding of a variant of human growth hormone to liver plasma membranes. Horm. Metab. Res., 14, 138-141.

YADLEY R. A., RODBARD D., CHRAMBACH A., 1973. Isohormones of human growth hormone. III. Isolation by preparative polyacrylamide gel electrophoresis and characterization. Endocrinology, 93, 866-873.

YMER S. I., HERINGTON A. C., 1985. Evidence for the specific binding of growth hormone to a receptor-like protein in rabbit serum. Mol. cell. Endocrinol., 41, 153-161.

YOKOYA S., FRIESEN H. G., 1986. Human growth hormone $(\mathrm{GH})$-releasing factor stimulates and somatostatin inhibits the release of rat $\mathrm{GH}$ variants. Endocrinology, 119, 2097-2105. 